\title{
The geologic role of polysulfides-Part II
}

\section{The solubility of acanthite and covellite in sodium polysulfide solutions*}

\author{
Paul L. Cloke \\ Department of Geology and Mineralogy, The University of Michigan
}

(Received 31 January 1963; accepted 20 May 1963)

\begin{abstract}
The solubility of synthetic low-temperature silver sulfide (acanthite) in solutions of sodium polysulfide of different concentrations, different ratios of sulfur to sulfide, and different acidity was determined. The solubility of acanthite increases with rising $\bar{y}$ (total $\mathrm{S}$ in sulfide and polysulfide species/total sulfide) with rising temperature, and with decreasing $\mathrm{pH}$ if $\tilde{y}$ is constant. For solutions saturated in sulfur, however, addition of acid causes the breakdown of polysulfide to hydrosulfide and sulfur and lowers the $\bar{y}$; the decrease of $\bar{y}$ lessens the solubility more than the lowering of $\mathrm{pH}$ raises it.

Using the activities of polysulfide ions calculated by CLOKE (1963) it is possible to deduce three complexes of silver ion, $\mathrm{Ag}\left(\mathrm{S}_{4}\right)_{2}{ }^{-3}, \mathrm{Ags}_{5} \mathrm{~S}_{4}{ }^{-3}$, and $\mathrm{Ag}(\mathrm{HS}) \mathrm{S}_{4}{ }^{-2}$, and to calculate the observed solubilities closely. The equilibrium constant for the reaction $\mathrm{Ag}_{2} \mathrm{~S}+4 \mathrm{~S}_{4}{ }^{-2}=2 \mathrm{Ag}\left(\mathrm{S}_{4}\right)_{2}{ }^{-3}+\mathrm{S}^{-2}$ is estimated as $2 \cdot 14 \times 10^{-8}$, and that for the reaction $\mathrm{Ag}_{2} \mathrm{~S}+2 \mathrm{~S}_{5}^{-2}+2 \mathrm{~S}_{4}^{-2}=2 \mathrm{AgS}_{5} \mathrm{~S}_{4}^{-3}+\mathrm{S}^{-2}$ is estimated as $1.74 \times 10^{-9}$. The constant for $\mathrm{Ag}_{2} \mathrm{~S}+\mathrm{H}^{+1}+\mathrm{HS}^{-1}+2 \mathrm{~S}_{4}^{-2}=2 \mathrm{Ag}(\mathrm{HS}) \mathrm{S}_{4}^{-2}$ is estimated as $2.95 \times 10^{4}$. Probably other complexes also exist.

The solubility data of HöıJTE and BECKERT (1935) can also be largely explained on the basis of the analogous complexes, $\mathrm{Cu}\left(\mathrm{S}_{4}\right)_{2}^{-3}$ and $\mathrm{CuS}_{4} \mathrm{~S}_{5}{ }^{-3}$. The equilibrium constant for the reaction $2 \mathrm{CuS}+\mathrm{S}_{3}^{-2}+3 \mathrm{~S}_{4}^{-2}=2 \mathrm{Cu}\left(\mathrm{S}_{4}\right)_{2}^{-3}+\mathrm{S}^{-2}$ is estimated as $5.00 \times 10^{-2}$ and for $2 \mathrm{CuS}+3 \mathrm{~S}_{4}^{-2}+$ $\mathrm{S}_{5}{ }^{-2}=2 \mathrm{CuS}_{4} \mathrm{~S}_{5}^{-3}+\mathrm{S}^{-2}$ as $3 \cdot 63 \times 10^{-7}$. No data are available to estimate a constant for $\mathrm{Cu}(\mathrm{HS}) \mathrm{S}_{4}^{-2}$.

Application of this study to ore deposition depends on somewhat uncertain extrapolations to higher temperatures and pressures. It is tentatively concluded that solubility increases with temperature at constant density, and increases with pressure at constant temperature. Thus, drop of temperature and pressure should cause deposition.
\end{abstract}

A critical consideration is the size of the stability field of polysulfides at elevated temperature and pressure. Data relevant to this question are uncertain; to illustrate the possible application of the present study it is assumed that an appreciable stability field exists under magmatic and hydrothermal conditions. A decrease in size of this stability field with changing temperature and pressure conditions could lead to ore deposition, as well as to deposition of barite, alunite, and other sulfates.

If equilibrium is maintained, either an increase or a decrease of $\mathrm{pH}$ would cause disproportionation of polysulfides and deposition of the dissolved sulfides. An increase of $\mathrm{pH}$ might be caused by reaction with limestone or by argillization of silicate rocks. A geologically feasible way of adding acid to the polysulfide solution is more difficult to visualize. Perhaps an initial separation of acid gases such as $\mathrm{HCl}$ and later recombination with the ore solution is possible. This should give a sulfide body containing native sulfur; the rarity of this type of ore suggests that this means of deposition is uncommon.

Either oxidation or reduction of the polysulfide solution would lead to deposition of sulfides. Oxidation might be brought about by reaction with hematite or magnetite to form pyrite and sulfate ion. The effectiveness of these reactions is limited by the small percentage of these minerals in most rocks. Reduction might be caused by reaction with organic material in black shales, or possibly with reducing gases present in volcanism.

Reaction with ferrous minerals, such as biotite, hornblende, or siderite, should also cause ore

* Published under the auspices of the Committee on Experimental Geology and Ceophysics and the Division of Geological Scienees at Harvard University. 
formation by removing sulfur from the polysulfide solution to form pyrite. Pyritization of wall rocks would thus appear as a cause, not a result, of ore deposition.

Until better chemical knowledge exists, it is difficult to know how polysulfide solutions may originate. In this paper it is assumed that an appreciable stability field exists under the conditions in which ore solutions evolve from magmas.

\section{INTRODUCTION}

Fon many years the mechanism of transport of most heavy metal sulfides which form vein deposits has remained a mystery. Because of the addition of water to the wall rocks to form alteration minerals adjacent to veins and the addition of sulfur and chalcophile elements such as copper, zinc, iron, lead etc., to the veins themselves, it seems evident that water, sulfur, and chalcophile metals must be present in the orecarrying medium. A major stumbling block, however, is that the chalcophile metal sulfides are insoluble in water and only arsenic, antimony, bismuth, mercury, and tin are known to form soluble sulfide complex ions of sufficient stability in aqueous solutions to dissolve large amounts of metal sulfide. Other complexes are known, e.g. $\mathrm{Pb}(\mathrm{HS})_{2}{ }^{0}$, and $\mathrm{AuS}^{-1}$, but these seem less likely to be effective for ore transport because of the relatively small amount of metal that can be carried. Apparently either sulfide ion is essentially absent if the metal is present largely as uncomplexed free cation, or chalcophile cations are absent if sulfide ion is present. BARTON (1957, 1959) has discussed this problem in more detail and concludes that probably chalcophile cations and sulfide ions are present only in trace amounts (e.g. $\mathrm{Zn}^{+2}$ at $10^{-9 \cdot 7} \mathrm{~m}, \mathrm{~Pb}^{+2}$ at $10^{-11 \cdot 7} \mathrm{~m}$, and $\mathrm{S}^{-2}$ at $10^{-10 \cdot 7} \mathrm{~m}$ ). Sulfate may be somewhat more abundant, e.g. $10^{-3 \cdot 6} \mathrm{~m}$ (BARTON, 1957). If both sulfide and sulfate were nearly absent the sulfur might be present principally in some intermediate valence state. Presumably the chalcophile elements would have to be present mostly as one or more complex ions.

This situation leaves several possibilities. If we assume dominantly aqueous solutions in which all sulfur species are in equilibrium, this imposes certain restrictions on the sulfur-containing ions that can co-exist (VALENSI, 1951 ; GARRELS and NAESER, 1958). The dominant species changes with variation of $\mathrm{Eh}$ and $\mathrm{pH}$. The region on an Eh-pH diagram which seems most reasonable for most sulfide-bearing, hydrothermal ore deposits lies close to the line, Eh (volts) $=0.22 \pm 0.04-0.059 \mathrm{pH}$ (BAK'TON, 1957, 1959; NATARAJAN, 1958), and near the neutral point. In this region at $25^{\circ} \mathrm{C}$ the principal sulfur species are $\mathrm{H}_{2} \mathrm{~S}, \mathrm{HS}^{-1}, \mathrm{~S}_{4}{ }^{-2}, \mathrm{~S}_{5}{ }^{-2}, \mathrm{~S}_{6}{ }^{-2}, \mathrm{~S}_{2} \mathrm{O}_{3}{ }^{-2}$, and $\mathrm{SO}_{4}{ }^{-2}$. BARNES and KULLERUD (1961) have concluded that slightly alkaline and somewhat more reducing conditions are necessary to explain the formation of pyrite-pyrrhotitemagnetite deposits. This is in keeping with the $\mathrm{Eh}-\mathrm{pH}$ diagrams by NataraJaN and GaRRELS (GARRELS, 1960) showing relations in the $\mathrm{Cu}-\mathrm{Fe}-\mathrm{S}-\mathrm{O}-\mathrm{H}$ system. These diagrams indicate that chalcopyrite can also exist stably with pyrite, pyrrhotite, and magnetite. At room temperature practically no polysulfide can be present at equilibrium with this assemblage. The mineral pair bornite-pyrite, chalcocitepyrite, and covellite-pyrite, however, are stable only at appreciably higher Eh where polysulfides are more important. By assuming the presence of $\mathrm{HS}^{-1}$ any appreciable transport of chalcophile elements must be accomplished by some complex which is more stable in this region than the metal sulfide. At room temperature* for many

* Data are lacking at higher temperatures. 
metals, complexes with $\mathrm{H}_{2} \mathrm{~S}, \mathrm{HS}^{-1}$, and $\mathrm{SO}_{4}^{-2}$ do not seem to meet this requirement. With the possible exception of copper and silver ions the known complexes of thiosulfate with common chalcophile cations $\left(\mathrm{Fe}^{+2}, \mathrm{Fe}^{+3}, \mathrm{Cu}^{+1}, \mathrm{Cu}^{+2}, \mathrm{Ag}^{+1}, \mathrm{Zn}^{+2}, \mathrm{~Pb}^{+2}\right.$ ) are likewise not stable enough (BJerrum, Schwarzenbach, and Siluén, 1958). Possibly they may be effective at higher temperatures. At room temperature copper and silver thiosulfate complexes would contain a few hundredths of a mg of metal per liter at $\mathrm{pH} 7$ in solutions $0 \cdot 1 \mathrm{M}$ in $\mathrm{HS}^{-1}$ and $1 \cdot 0 \mathrm{M}$ in $\mathrm{S}_{2} \mathrm{O}_{3}{ }^{-2}$.

HöLTJE and BECKERT (1935) measured the solubility of CuS in aqueous sodium and potassium polysulfides and found that solutions 0.64 molar and somewhat undersaturated in sulfur dissolved, respectively, 270 and $325 \mathrm{mg} \mathrm{Cu} / \mathrm{l}$. at $25^{\circ} \mathrm{C}$. $\mathrm{By}$ projecting their data to saturation in $\mathrm{S}$ and to $75^{\circ} \mathrm{C}$ solubilities of 0.9 and $1.6 \mathrm{~g}$ Cu/l. are estimated.

The solubility of CuS calculated at saturation in $\mathrm{S}$ in $0.64 \mathrm{M} \mathrm{Na} \mathrm{Na}_{2} \mathrm{~S}_{\alpha}$ solutions at $25^{\circ} \mathrm{C}$ from the constants derived in this paper is $0.357 \mathrm{~g} \mathrm{Cu} / 1$. Even though the experimental conditions were greatly different from natural environments, these solubilities seem geologically significant.

In view of thesc considerations and solubility data for CuS it seemed worthwhile to investigate the solubility of other sulfides in polysulfide solutions. Silver sulfide was chosen for the first investigation.

\section{Terminology}

The use of such terms or symbols as "monosulfide", "polysulfide", $\bar{y}, x$, parenthesis, square brackets and others is the same as used in the first paper of this series (ClOKE, 1963). For the reader's convenience a fow definitions are repeated here: $m$, molality of a substance; monosulfide, the sum $\sum_{x=1}^{\infty}\left\{\left[\mathrm{H}_{2} \mathrm{~S}_{x}\right]\left|\left[\mathrm{HS}_{x}^{-1}\right]\right|\left[\mathrm{S}_{x}{ }^{-2}\right]\right\}$; (N), the activity of the substance $\mathrm{N}$ in moles/ liter; $[\mathrm{N}]$, the concentration of the substance $\mathrm{N}$ in moles/liter; polysulfide, as a noun: the sum, $\sum_{x=2}^{\infty}(x-1)\left(\left[\mathrm{S}_{x}{ }^{-2}\right]+\left[\mathrm{HS}_{x}{ }^{-1}\right]+\left[\mathrm{H}_{2} \mathrm{~S}_{x}\right]\right)$, as an adjective: containing or composed of one or more polysulfide species; $x$, the number of atoms of sulfur in a sulfide or polysulfide species; $\bar{y}$, the ratio of the sum of monosulfide plus polysulfide to monosulfide, i.e.

$$
\frac{\sum_{x=1}^{\infty} x\left(\left[\mathrm{H}_{2} \mathrm{~S}_{x}\right]+\left[\mathrm{HS}_{x}^{-1}\right]+\left[\mathrm{S}_{x}^{-2}\right]\right)}{\sum_{x=1}^{\infty}\left(\left[\mathrm{H}_{2} \mathrm{~S}_{x}\right]+\left[\mathrm{HS}_{x}^{-1}\right]+\left[\mathrm{S}_{x}^{-2}\right]\right)}
$$

\section{Experimental Method}

The work was performed by first making up $\mathrm{Na}_{2} \mathrm{~S}$ solutions of known strength, adding weighed amounts of flowers of sulfur and an excess of acanthite*. The mixture was then stirred under a nitrogen atmosphere with a teflon-coated magnetic bar in a tightly stoppered flask or jar for several hours. In some cases $\mathrm{H}_{2} \mathrm{~S}$ was bubbled through the solution. A few determinations were made by adding $\mathrm{AgNO}_{3}$ solution to the polysulfide to approach equilibrium from the supersaturated side. Some of the runs were made in polyethylene flasks and others in Pyrex. No differences were found on this account, and no frosting of the Pyrex was seen.

After filtration under a nitrogen atmosphere through a sintered glass filter the solution was tested for Tyndall effect. Then a large aliquot ( 100 or $200 \mathrm{ml}$ ) was transferred to a water solution

* Acanthite is the low temperature or $\alpha$ form of $\mathrm{Ag}_{2} \mathrm{~S}$; the high temperature or $\beta$-form is argentite. 
containing excess $\mathrm{NaOH}$ and the polysulfide oxidized to sulfate by $\mathrm{H}_{2} \mathrm{O}_{2}$. This caused the reprecipitation of acanthite. The acanthite thus obtained was weighed in a sintered glass filter crucible (testing the filtrate and washings for Tyndall effect). Then the acanthite was dissolved in hot concentrated $\mathrm{HNO}_{3}$, the solution neutralized with $\mathrm{NH}_{4} \mathrm{OH}$ and barely acidified with $\mathrm{HNO}_{3}$. This solution was analysed by potentiometric titration with standard KI using a polished silver billet electrode coupled through a $\mathrm{NaNO}_{3}$ salt bridge (capillary junction with very slow flow) to a saturated calomel electrode. The KI solution was made by weighing KI crystals and making up to volume; its titer was checked against standard $\mathrm{AgNO}_{3}$. The titration blank corresponded to about $0.05 \mathrm{mg} \mathrm{Ag} / \mathrm{l}$. The precipitated $\mathrm{AgI}$ was then weighed in some of the early runs. All three analyses agreed.

Smaller aliquots were always taken for determination of thiosulfate. For those cases which could not be easily calculated from the initial amounts of ingredients, aliquots were taken for analysis of total $\mathrm{S}$ and monosulfide.

Analyses for thiosulfate, total S, monosulfide etc., were carried out as described in the first paper of this series (ClOKF, 1963). $\mathrm{Na}_{2} \mathrm{~S}$ solution was also prepared as previously described.

The acanthite was prepared by dissolving about $60 \mathrm{~g}$ of silver nitrate in a liter of water treated for $2 \mathrm{hr}$ by nitrogen and slowly adding $\mathrm{H}_{2} \mathrm{~S}$ from a commercial tank. The precipitate was washed by $4 \mathrm{l}$. of nitrogen-treated distilled water.

Heating was accomplished by means of the heat from the stirrer motor, or by a combined hot plate and stirrer.

\section{Previous Work}

Much of the earlier work relating to the present investigation has been discussed by the author in the first paper of this series (CLOKE, 1963). In this section only the studies relating directly to the solubility of acanthite or covellite will be considered.

CLOKE (1963) chose the free energy of formation of acanthite as $-9 \cdot 30 \mathrm{kcal} / \mathrm{mole}$ and of sulfide ion as $21.42 \mathrm{kcal} / \mathrm{mole}$. LATTMER (1952) lists the free energy of formation of silver ion as $18.430 \mathrm{kcal} / \mathrm{mole}$. From these values the solubility product of silver sulfide was calculated as $2 \cdot 85 \times 10^{-50}$. This differs from Latrmen's value principally because he used a different free energy of formation for sulfide ion.

Treadwell and Hepenstrick (1949) measured the solubility of silver sulfide in NaHS solutions saturated $\mathrm{H}_{2} \mathrm{~S}$. The measurement was done colorimetrically after precipitation with sucrose to form a brown silver sol. After doing this at different $\mathrm{pH}$ 's thoy deduced the following constants:

\begin{tabular}{cc}
\hline Reaction & Constant \\
\hline $\mathrm{Ag}^{+1}+\mathrm{H}_{2} \mathrm{~S}=\mathrm{AgSH}+\mathrm{H}^{+1}$ & $\frac{(\mathrm{AgSH})\left(\mathrm{H}^{+1}\right)}{\left(\mathrm{Ag}^{+1}\right)\left(\mathrm{H}_{2} \mathrm{~S}\right)}=1.76 \times 10^{9}$ \\
$\mathrm{AgSH}=\mathrm{AgS}^{-1}+\mathrm{H}^{+1}$ & $\frac{\left(\mathrm{AgS}^{-1}\right)\left(\mathrm{H}^{+1}\right)}{(\mathrm{AgSH})}=5 \cdot 25 \times 10^{-6}$
\end{tabular}

From these constants a free energy of formation of $\mathrm{AgS}^{-1}$ can be deduced and a free energy and an equilibrium constant of the reaction $\mathrm{Ag}_{2} \mathrm{~S}+\mathrm{S}^{-2}=2 \mathrm{AgS}^{-1}$ calculated. This constant, $\left(\mathrm{AgS}^{-1}\right)^{2} /$ $\left(\mathrm{S}^{-2}\right)$, is $\mathbf{0} \cdot 275$. Since this implies rather high solubilities of acanthite in alkaline sulfide solutions, where actually the solubility is very low, it appears that an error has been made. The data can be explained by the following constants:

\begin{tabular}{cc}
\hline Reaction & Constant \\
\hline $\mathrm{Ag}^{+1}+\mathrm{H}_{2} \mathrm{~S}=\mathrm{AgSH}+\mathrm{H}^{+1}$ & $\frac{(\mathrm{AgSH})\left(\mathrm{H}^{+1}\right)}{(\mathrm{Ag})\left(\mathrm{H}_{2} \mathrm{~S}\right)}=1.7 \pm 0.2 \times 10^{9}$ \\
$\mathrm{Ag}^{+1}+2 \mathrm{H}_{2} \mathrm{~S}=\mathrm{Ag}(\mathrm{SH})_{2}^{-1}+2 \mathrm{H}^{+1}$ & $\frac{\left(\mathrm{Ag}(\mathrm{SH})_{2}^{-1}\right)\left(\mathrm{H}^{+1}\right)^{2}}{\left(\mathrm{Ag}^{+1}\right)\left(\mathrm{H}_{2} \mathrm{~S}\right)^{2}}=1.0 \pm 0.4 \times 10^{4}$. \\
\hline
\end{tabular}


OL'SHANSKII et al. (1959) have studied the solubility of $\mathrm{Ag}_{2} \mathrm{~S}$ at temperatures from $25^{\circ}$ to $160^{\circ}$ in aqueous solutions containing $\mathrm{NaCl}$ and saturated with $\mathrm{H}_{2} \mathrm{~S}$ at $25^{\circ} \mathrm{C}$. They found solubilities at $25^{\circ} \mathrm{C}$, an order of magnitude lower than those reported by Treadwell and HePENSTRICK (1949). OL'Shanskir et al. used $\mathrm{NaCl}$ or $\mathrm{HCl}$ to keep the ionic strength constant while TreadweII and Hepenstrack used $\mathrm{NaClO}_{4}$ or $\mathrm{HClO}_{4}$. It thus seems likely that the latter may aetually have determined the amount of silver-hydrosulfide-perchlorate complexes and that OL'sHaNkrr et al. obtained the concentrations of silver-hydrosulfide (or silver-hydrosulfide-chloride?) complexes. In this paper the constants just presented are considered to be incorrect because of incorporation of perchlorate into the complexes.

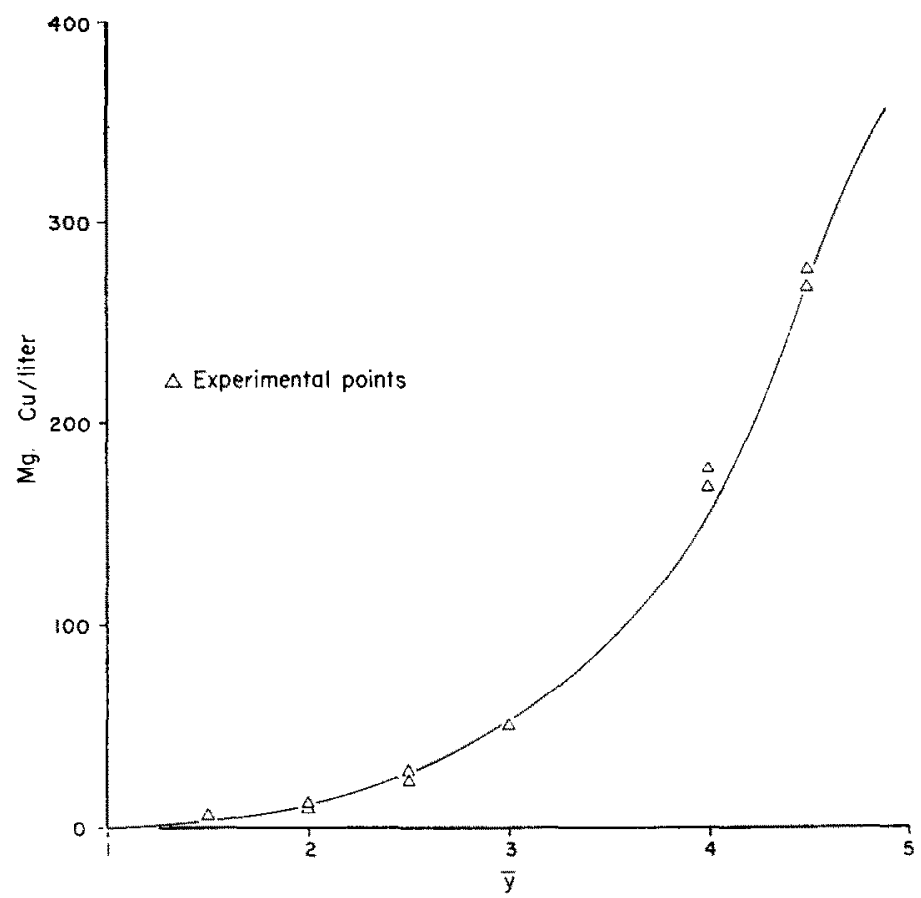

Fig. 1. Solubility of covellite in $0.64 \mathrm{M} \mathrm{Na} \mathrm{s}_{x}$ solutions al $25^{\circ} \mathrm{C}$. Fxperimental points from HöLtJE and BECKERT (1935). Solid line calculated.

The data of OL'sHanskn et al. show that the solubility of $\mathrm{Ag}_{2} \mathrm{~S}$ increases with temperature, apparently more rapidly than the increase of solubility of $\mathrm{CuS}$ in polysulfide solutions with temperature (HöLTJE and BECKERT, 1935) or of acanthite in polysulfide solutions (reported here).

HözTJE and BECKERT (1935) measured the solubility of CuS in 0.64 M sodium and potassium polysulfide solutions at $25^{\circ} \mathrm{C}$ and various $\vec{y}$ 's. Figure 1 shows the measured values in $\mathrm{Na}_{2} \mathrm{~s}_{x}$ solutions and a line giving the solubilities calculated as described in a later section. In addition they measured the solubility in sodium polysulfide with a $\bar{y}$ of 3 ai $50^{\circ}$ and $75^{\circ} \mathrm{C}$ (Fig. 2) and at different concentrations (Fig. 3).

Previous discussions of the role of polysulfides in ore-carrying solutions have been published by CLOKE (1958 and 1961). The conclusions presented there are revised in this paper.

\section{EXPERIMENTAL Results}

The measured solubilities are compiled in Table 1 and represented graphically in Figs. 4, 5, 6, and 7: In Fig. 4 the solubility in $\mathrm{mg}$ of Ag contained in one liter of solution is plotted against $\bar{y}$. The lines show the solubilities as calculated from the constants derived in the following section. 


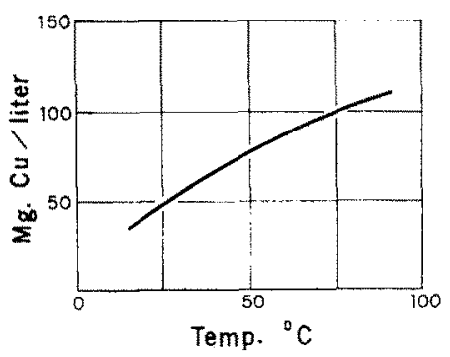

Fig. 2. Solubility of covellite in $0.64 \mathrm{M} \mathrm{Na}_{2} \mathrm{~S}_{3}$ solution with changing temperature (after HöLTJE and BECKERT, 1935).

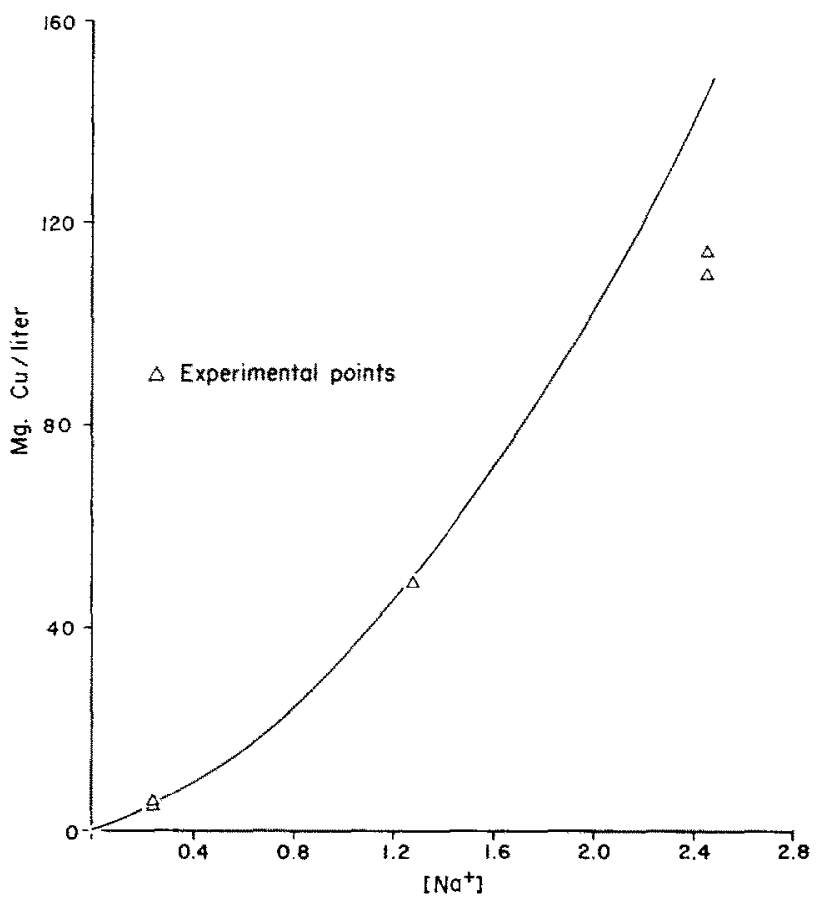

Fig. 3. Solubility of covellite in $\mathrm{Na}_{2} \mathrm{~S}_{3}$ solutions of different concentrations at $25^{\circ} \mathrm{C}$. Experimental points from HöLTJE and BECKERT (1935). Solid line calculated.

Figure 5 shows the measured solubility data plotted against $\left[\mathrm{Na}^{+1}\right]$ for three different values of $\bar{y}$.

Figure 6 shows the change of solubility with temperature for solutions $1.0 \mathrm{M}$ in $\mathrm{Na}+1$ and at two $\bar{y}$ values. The lines are dashed between $30^{\circ} \mathrm{C}$ and $90^{\circ} \mathrm{C}$ because solubilities were not measured at intermediate temperatures. Since HöLTJE and BECKERT (1935) found a nearly linear increase for the solubility of CuS with temperature, it seems likely that the dashed lines indicated are not greatly in error.

The experimental data for solutions $1.0 \mathrm{M}$ in $\mathrm{Na}^{+1}$ are also plotted in Fig. 7 against the measured $\mathrm{pH}$. All solid lines are calculated. The dashed line at the left extending from $\mathrm{pH} 6.90$ to $\mathrm{pH} 7.72$ represents solutions saturated in both $\mathrm{H}_{2} \mathrm{~S}$ and $\mathrm{S}$; the points near $\mathrm{pH} 6.90$ indicate the solubility of acanthite when $\left[\mathrm{Na}^{+1}\right]=0.1$ and the points near $\mathrm{pH} 7.67$ the solubility when $\left[\mathrm{Na}^{+1}\right]=1 \cdot 0$. 
Table 1. Measured solubilities

\begin{tabular}{|c|c|c|c|c|c|c|}
\hline Moles $\mathrm{Na}^{+1} / \mathrm{l}$ & $\bar{y}$ & $t^{\circ} \mathrm{C}$ & $\mathrm{Hr}$ & $\mathrm{pH}$ & $\mathrm{mg} \mathrm{Ag} / \mathrm{l}$ & $\begin{array}{c}\text { Moles } \\
\mathrm{S}_{2} \mathrm{O}_{3}^{-2} / 1\end{array}$ \\
\hline $1 \cdot 000$ & $4 \cdot 9$ & $31 \cdot 0$ & 50 & $11 \cdot 34$ & $90 \cdot 5$ & 0.004 \\
\hline 1.000 & $4 \cdot 9$ & $30 \cdot 5$ & 47 & $11 \cdot 00$ & $88 \cdot 2$ & 0.023 \\
\hline $1 \cdot 000$ & $4 \cdot 5$ & $30 \cdot 5$ & 90 & $11 \cdot 75$ & $55 \cdot 5$ & $0 \cdot 011$ \\
\hline $1 \cdot 000$ & $4 \cdot 0$ & $30 \cdot 0$ & 8 & $12 \cdot 28$ & $21 \cdot 0$ & 0.007 \\
\hline 1.000 & $4 \cdot 0$ & $30 \cdot 0$ & 16 & $12 \cdot 37$ & $18 \cdot 8$ & 0.007 \\
\hline $1 \cdot 000$ & $4 \cdot 0$ & $30 \cdot 0$ & 16 & & $20 \cdot 5$ & 0.007 \\
\hline 1.000 & $4 \cdot 1$ & $30 \cdot 0$ & 46 & & $24 \cdot 0$ & $0 \cdot 008$ \\
\hline 1.000 & $4 \cdot 0$ & $30 \cdot 5$ & 94 & $12 \cdot 20$ & $22 \cdot 6$ & 0.009 \\
\hline 1.000 & $3 \cdot 5$ & $32 \cdot 8$ & 94 & $12 \cdot 50$ & $7 \cdot 9$ & 0.015 \\
\hline 1.000 & $3 \cdot 0$ & $30 \cdot 0$ & 52 & $12 \cdot 88$ & $3 \cdot 00$ & $0 \cdot 010$ \\
\hline 1.000 & $3 \cdot 0$ & $30 \cdot 0$ & 91 & $12 \cdot 55$ & $2 \cdot 96$ & 0.011 \\
\hline 1.000 & $2 \cdot 0$ & 31.5 & 24 & $12 \cdot 86$ & 0.02 & 0.023 \\
\hline $1.000^{*}$ & $2 \cdot 9$ & $30 \cdot 0$ & 16 & $8 \cdot 40$ & $75 \cdot 0$ & 0.007 \\
\hline $1 \cdot 000^{*}$ & $1 \cdot 3$ & $30 \cdot 0$ & 87 & $7 \cdot 65$ & $38 \cdot 0$ & 0.004 \\
\hline $1 \cdot 000^{*}$ & $1 \cdot 3$ & $28 \cdot 0$ & 21 & $7 \cdot 69$ & 37.9 & 0.002 \\
\hline $1 \cdot 000$ & $5 \cdot 0$ & $88 \cdot 0$ & 22 & & $208 \cdot 5$ & 0.033 \\
\hline 1.000 & $4 \cdot 0$ & $89 \cdot 0$ & 40 & & $53 \cdot 2$ & 0.045 \\
\hline 0.600 & $4 \cdot 9$ & $35 \cdot 0$ & 40 & $10 \cdot 33$ & $45 \cdot 0$ & 0.006 \\
\hline 0.600 & $4 \cdot 0$ & $34 \cdot 8$ & 40 & $11 \cdot 80$ & $11 \cdot 2$ & 0.006 \\
\hline 0.600 & $3 \cdot 0$ & 34.5 & 51 & $12 \cdot 35$ & $1 \cdot 4$ & 0.010 \\
\hline 0.600 & $2 \cdot 5$ & 33.5 & 148 & $12 \cdot 50$ & 0.7 & 0.008 \\
\hline $0 \cdot 200$ & $4 \cdot 9$ & $32 \cdot 0$ & 98 & & $4 \cdot 8$ & 0.005 \\
\hline 0.200 & $4 \cdot 9$ & $32 \cdot 0$ & 104 & $10 \cdot 50$ & $6 \cdot 3$ & 0.004 \\
\hline $0 \cdot 200$ & $4 \cdot 0$ & $32 \cdot 5$ & 48 & $11 \cdot 53$ & $1 \cdot 87$ & 0.006 \\
\hline 0.200 & $4 \cdot 0$ & $33 \cdot 5$ & 119 & $11 \cdot 59$ & $2 \cdot 10$ & 0.008 \\
\hline $0 \cdot 200$ & $3 \cdot 0$ & $32 \cdot 0$ & 50 & $12 \cdot 05$ & $0 \cdot 35$ & 0.006 \\
\hline $0 \cdot 100^{*}$ & $1 \cdot 03$ & $25 \cdot 0$ & 21 & 6.88 & $0 \cdot 6$ & 0.001 \\
\hline $0 \cdot 100^{*}$ & 1.01 & 29.5 & 21 & $6 \cdot 92$ & $1 \cdot 0$ & 0.001 \\
\hline
\end{tabular}

* $\mathrm{H}_{2} \mathrm{~S}$ added.

\section{Generul discussion}

\section{Calculations}

The results obtained suggest that the amount of acanthite that can be dissolved by polysulfide solutions may be of considerable geologic interest. To obtain a clearer understanding of the means of solution it is desirable to derive the forms of the complex ions present and their stability constants. To do this the data presented in the first paper of this series (Cloke, 1963) have been used.

\section{Effect of previous known complexes}

The only silver complexes formerly recognized in sulfide solutions are those responsible for the solubilities observed by TreapweLl and HePEnstrick (1949) and by Or'sHanskir et al. (1959). The former apparently include perchlorate ion, and thus were not present in the ex. periments described here. The latter are negligible in comparison with the polysulfide complexes.

\section{Polysulfide complexes}

Because no complexes with $\mathrm{HS}^{-1}, \mathrm{~S}^{-2}$, or $\mathrm{OH}^{-1}$ appear to be strong enough to account for the observed solubilities, it appears that one or more complexes with polysulfide ions must be present. No other anions are present in sufficient amounts or have stable enough complexes with $\mathrm{Ag}^{+1}$ to account for the observations. To deduce which complexes are present, however, it is necessary to make a few simplifying assumptions. 

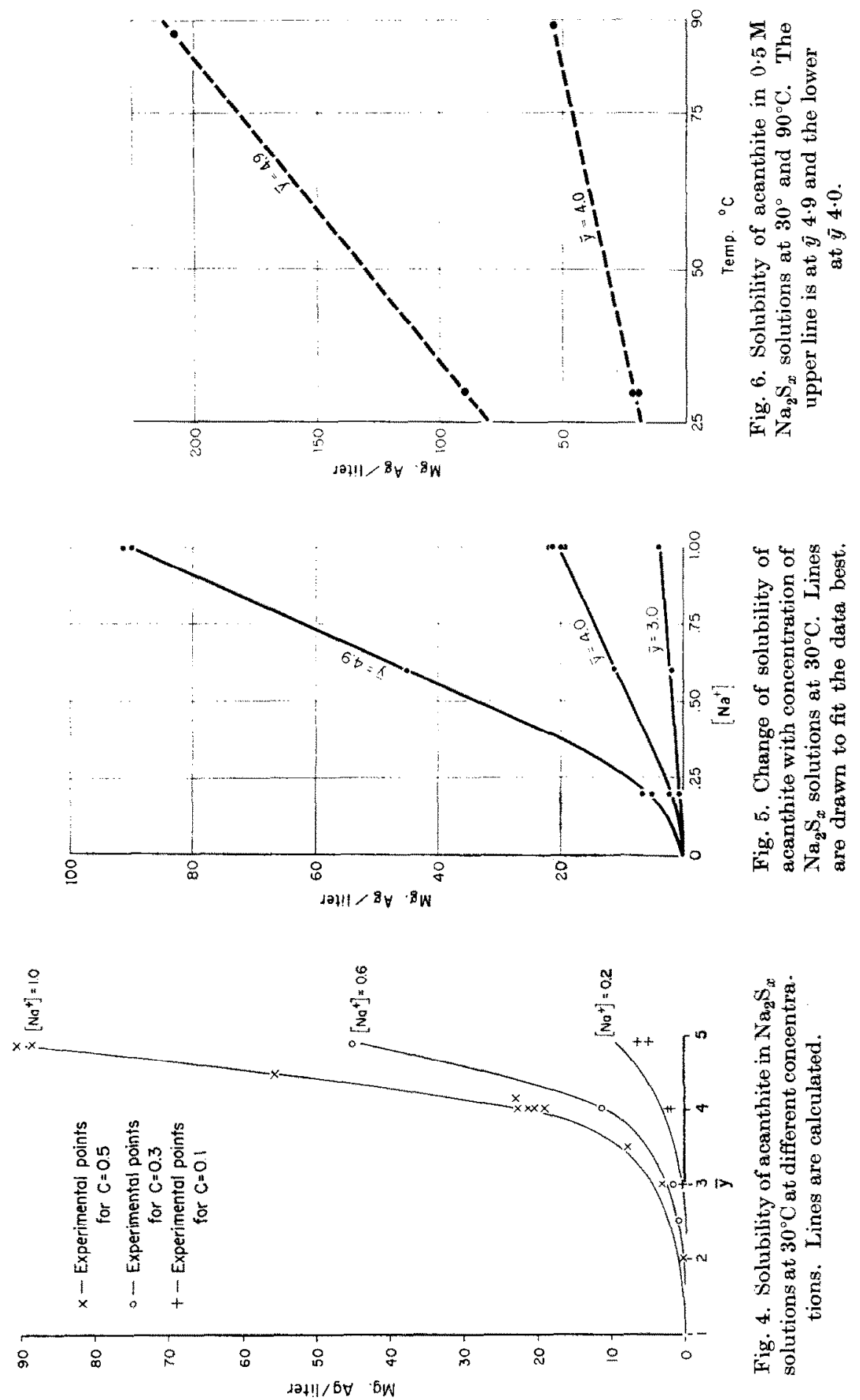


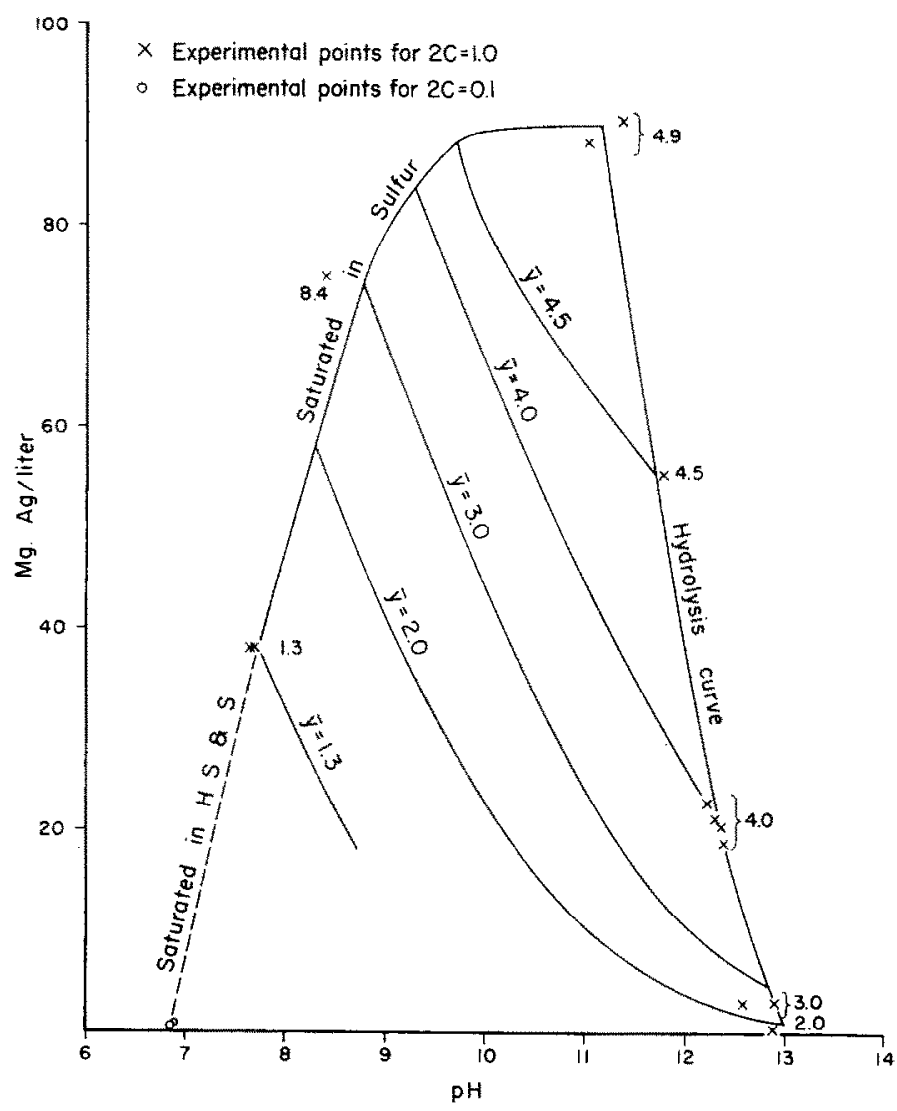

Fig. 7. Solubility of acunthite in solutions $1.0 \mathrm{M} \mathrm{in} \mathrm{Na}^{+1}$ as a function of $\mathrm{pH}$ and $\bar{y}$. All solid lines are calculated. Figures on the graph refer to $\bar{y}$.

First of all it appears from Fig. 4 that increasing $S$ content at constant concentration (i.e. increasing $\bar{y}$ ) causes a marked increase of solubility starting at about $\bar{y}=3$. Since disulfide and trisulfide ion concentrations would be expected to decrease as $\bar{y}$ increases above 3 , it seems probable that neither of these ions is significantly involved in the solution process.

\section{Silver polysulfide complexes}

The procedure followed next was largely a trial and error method. Thus a complex, such as Ags $_{5}^{-1}$, was ussumed to alcount for the entire anount of dissolved Ag at some measured point. The stability constant was then derived, and the amount of the complex which would be present at all other experimental points was calculated from the stability constant. Other complexes of the same form, such as $\mathrm{Ags}_{4}^{-1}$, were then assumed to make up the difference between the observed and calculated amounts until the best fit was obtained. If the fit was poor, then that particular form of complex was rejected. It became apparent from this procedure that a large percentage of the increase in solubility along the hydrolysis curve between $\bar{y}=4$ and $\bar{y}=5$ is due to the very marked decrease in the activity of sulfide ion.

A more direct path to the final result is to note that argentous ion often has a co-ordination number of 2 in complexes, as well as in acanthite (EwaLd and HERMaNN, 1931). It is, therefore, logical to try complexes with one argentous ion and two polysulfide ions. Because of the marked effect of decreasing sulfide ion activity with increasing $y$ it was found that, in general, complexes with tetrasulfide ion give a better fit to the experimental data than do complexes with pentasulfide ion. The complex, $\operatorname{Ag}\left(S_{4}\right)_{2}^{-3}$, thus seems to be a logical choice. Testing of this complex 
against the experimental data gives a good fit except at high $\vec{y}$. The discrepancy there can be largely corrected by assuming the presence of the $\mathrm{AgS}_{4} \mathrm{~S}_{5}{ }^{-3}$ complex also.

At lower $\mathrm{pH}$ 's the agreement of the measured solubility and that calculated using only these two complexes becomes progressively worse. This discrepaney can be corrected by assuming that one of the polysulfide ions is displaced by $\mathrm{HS}^{-1}$ at lower $\mathrm{pH}$ 's. Either $\mathrm{Ag}(\mathrm{HS}) \mathrm{S}_{4}^{-2}$ or $\mathrm{Ag}(\mathrm{HS}) \mathrm{S}_{5}^{-2}$ can be used to give satisfactory agreement with all the experimental points. Probably the ion, $\mathrm{Ag}(\mathrm{HS}) \mathrm{S}_{4}^{-2}$, is more important since it would be produced by displacement of either tetrasulfide ion from $\mathrm{Ag}\left(\mathrm{S}_{4}\right)_{2}{ }^{-3}$ or of pentasulfide ion from $\mathrm{AgS}_{4} \mathrm{~S}_{5}{ }^{-3}$. Moreover, $\mathrm{Ag}\left(\mathrm{S}_{4}\right)_{2}{ }^{-3}$ always dominates in amounts over $\mathrm{AgS}_{4} \mathrm{~S}_{5}{ }^{-3}$, which also suggests that $\left[\mathrm{Ag}(\mathrm{HS}) \mathrm{S}_{4}{ }^{-2}\right]$ is larger. For the calculation of the curves in Fig. $7, \mathrm{Ag}(\mathrm{HS}) \mathrm{S}_{4}{ }^{-2}, \mathrm{Ag}\left(\mathrm{S}_{4}\right)_{2}{ }^{-3}$, and $\mathrm{AgS}_{4} \mathrm{~S}_{5}{ }^{-3}$ were used; the results are presented in Table 2. If $\mathrm{Ag}(\mathrm{HS}) \mathrm{S}_{5}{ }^{-2}$ is used instead, the calculated solubilities differ at most by three or four $\mathrm{mg} / \mathrm{l}$

Table, 2. Calculated solubilities of acanthite

\begin{tabular}{|c|c|c|c|c|c|c|c|c|c|}
\hline \multirow[b]{2}{*}{$|\mathbf{N a}+1|$} & \multirow[b]{2}{*}{$\bar{y}$} & \multirow[b]{2}{*}{$\mathrm{pH}$} & \multicolumn{3}{|c|}{ Negative log } & \multicolumn{3}{|c|}{$\operatorname{mg} / \mathrm{l}$} & \multirow{2}{*}{$\begin{array}{c}\text { Total } \\
\text { dissolved } \\
\text { Ag, mg/l. }\end{array}$} \\
\hline & & & $\left(A g\left(S_{4}\right)_{2}^{-3}\right)$ & $\left(\mathrm{AgS}_{4} \mathrm{~S}_{5}^{-3}\right)$ & $\left(\mathrm{Ag}(\mathrm{HS}) \mathrm{S}_{4}^{-2}\right)$ & $\operatorname{Ag}\left(S_{4}\right)_{2}^{-3}$ & $\operatorname{AgS}_{4} \mathrm{~S}_{5}-3$ & $\mathrm{Ag}(\mathrm{HS})\left(\mathrm{S}_{4}\right)^{-2}$ & \\
\hline 1.0 & $4 \cdot 9$ & $11 \cdot 12$ & $3 \cdot 81$ & $4 \cdot 12$ & 6.07 & 62.0 & $27 \cdot 6$ & $0 \cdot 2$ & $89 \cdot 8$ \\
\hline $1 \cdot 0$ & $4 \cdot 5$ & $11 \cdot 69$ & 3.95 & $4 \cdot 56$ & $5 \cdot 86$ & $44 \cdot 8$ & $10 \cdot 0$ & $0 \cdot 3$ & $5 \check{5} 5 \cdot 1$ \\
\hline$I \cdot 0$ & $4 \cdot 5$ & $11 \cdot 00$ & $3 \cdot 91$ & $4 \cdot 43$ & $5 \cdot 37$ & $49 \cdot 2$ & $13 \cdot 5$ & $1 \cdot 0$ & $63+7$ \\
\hline $1 \cdot 0$ & $4 \cdot 5$ & $10 \cdot 00$ & $3 \cdot 86$ & $4 \cdot 23$ & $4 \cdot 80$ & $55 \cdot 2$ & $21 \cdot 4$ & $3 \cdot 9$ & 80.5 \\
\hline $1 \cdot 0$ & $4 \cdot \tilde{5}$ & $9 \cdot 69$ & $3 \cdot 84$ & $4 \cdot 15$ & $4 \cdot 66$ & $57 \cdot 8$ & $25 \cdot 8$ & $5 \cdot 3$ & 88.9 \\
\hline $1 \times 0$ & $4 \cdot 0$ & $12 \cdot 33$ & $4 \cdot 34$ & $5 \cdot 33$ & $5 \cdot 73$ & $18 \cdot 8$ & $1 \cdot 7$ & 0.4 & $20 \cdot 9$ \\
\hline $1 \cdot 0$ & 4.0 & 11.00 & 4.05 & $4 \cdot 76$ & $4 \cdot 98$ & $35 \cdot 6$ & $6 \cdot 3$ & $2 \cdot 5$ & $44 \cdot 4$ \\
\hline 1.0 & $4 \cdot 0$ & $10 \cdot 00$ & 3.93 & $4 \cdot 40$ & $4 \cdot 56$ & $46 \cdot 2$ & $14 \cdot 5$ & $6 \cdot 6$ & $67 \cdot 3$ \\
\hline $1 \cdot 0$ & 4.0 & $9 \cdot 27$ & $3 * 90$ & $4 \cdot 21$ & $4 \cdot 30$ & $50 \cdot 4$ & $22 \cdot 4$ & $12 \cdot 2$ & $85 \cdot 0$ \\
\hline 1.0 & 3.0 & $12 \cdot 80$ & 4.98 & $6 \cdot 32$ & $5 \cdot 82$ & $4 \cdot 2$ & $0 \cdot 2$ & 0.4 & $4 \cdot 8$ \\
\hline $1 \cdot 0$ & $3 \cdot 0$ & $12 \cdot 00$ & $4 \cdot 66$ & 5.81 & $5 \cdot 23$ & $8 \cdot 8$ & $0 \cdot 6$ & $1 \cdot 4$ & $10 \cdot 8$ \\
\hline 1.0 & $3 \cdot 0$ & $11 \cdot 00$ & $4 \cdot 35$ & $5 \cdot 23$ & $4 \cdot 78$ & $17 \cdot 9$ & $2 \cdot 1$ & $4 \cdot 3$ & $24 \cdot 3$ \\
\hline 1.0 & 3.0 & $10 \cdot 00$ & $4 \cdot 15$ & $4 \cdot 76$ & $4 * 36$ & $28 \cdot 4$ & 6.3 & $10 \cdot 6$ & $45 \cdot 3$ \\
\hline $1 \cdot 0$ & $3 \cdot 0$ & $9 \cdot 40$ & 4.09 & $4 \cdot 54$ & $4 \cdot 16$ & $32 \cdot 4$ & $10 \cdot 5$ & $16 \cdot 7$ & $59 \cdot 6$ \\
\hline 1.0 & 3.0 & $8 \cdot 78$ & 4.05 & $4 \cdot 36$ & $3 \cdot 96$ & 35.5 & $15 \cdot 8$ & $26 \cdot 8$ & $78 \cdot 1$ \\
\hline 1.0 & $2 \cdot 0$ & $12 \cdot 98$ & $5 \cdot 71$ & $7 \cdot 23$ & $6 \cdot 09$ & 0.8 & - & $0 \cdot 2$ & $1 \cdot 0$ \\
\hline 1.0 & $2 \cdot 0$ & $12 \cdot 00$ & $5 \cdot 20$ & 6.53 & $5 \cdot 25$ & $2 \cdot 5$ & 0.1 & 1.4 & $4 \cdot 0$ \\
\hline $1 \cdot 0$ & $2 \cdot 0$ & 11.00 & $4 \cdot 81$ & 5.84 & $4 \cdot 74$ & 6.1 & 0.5 & $4 \cdot 4$ & 11.0 \\
\hline 1.0 & $2 \cdot 0$ & $10 \cdot 00$ & $4 \cdot 54$ & $5 \cdot 29$ & $4 \cdot 34$ & $11 \cdot 4$ & 1.9 & 11.0 & $24 \cdot 3$ \\
\hline 1.0 & 2.0 & $9 \cdot 00$ & $4 \cdot 41$ & $4 \cdot 88$ & 4.01 & $15 \cdot 4$ & 4.7 & $23 \cdot 6$ & $43 \cdot 7$ \\
\hline 1.0 & $2 \cdot 0$ & 8.29 & $4 \cdot 38$ & $4 \cdot 69$ & $3 \cdot 80$ & $16 \cdot 6$ & 7.4 & $38 \cdot 1$ & $62 \cdot 1$ \\
\hline $1 \cdot 0$ & $1 \cdot 3$ & $7 \cdot 72$ & 5.03 & $5 \cdot 33$ & 3.87 & $3 \cdot 7$ & $1 \cdot 7$ & $32 \cdot 6$ & $38 \cdot 0$ \\
\hline $0 \cdot 6$ & $4 \cdot 9$ & $11 \cdot 02$ & $4 \cdot 11$ & $4 \cdot 42$ & $6 \cdot 27$ & $30 \cdot 0$ & $13 \cdot 6$ & $0 \cdot 1$ & 43.7 \\
\hline $0 \cdot 6$ & $4 \cdot 0$ & $12 \cdot 20$ & $4 \cdot 62$ & $5 \cdot 60$ & 5.93 & $9 \cdot 4$ & $0 \cdot 9$ & $0 \cdot 3$ & $10 \cdot 6$ \\
\hline 0.6 & 3.0 & $12 \cdot 66$ & $5 \cdot 25$ & 6.55 & 6.02 & $2 \cdot 2$ & 0.1 & 0.2 & $2 \cdot 5$ \\
\hline $0 \cdot 6$ & $2 \cdot 5$ & $12 \cdot 78$ & $5 \cdot 57$ & $6 \cdot 99$ & $6 \cdot 12$ & 1.0 & - & $0 \cdot 2$ & $1 \cdot 2$ \\
\hline 0.2 & $4 \cdot 9$ & $10 \cdot 81$ & $4 \cdot 74$ & 5.05 & $6 \cdot 69$ & $6 \cdot 3$ & 2.9 & - & $9 \cdot 2$ \\
\hline $0 \cdot 2$ & $4: 0$ & $11 \cdot 78$ & $5 \cdot 11$ & $5 \cdot 95$ & $6 \cdot 39$ & $2 \cdot 7$ & 0.3 & 0.1 & $3 \cdot 1$ \\
\hline 0.2 & $3 \cdot 0$ & $12 \cdot 33$ & $5 \cdot 76$ & 6.98 & $6 \cdot 44$ & $0 \cdot 6$ & - & $0 \cdot 1$ & 0.7 \\
\hline
\end{tabular}

Activity coefficients for polysulfide complex ions

The ions $\mathbf{S}-\mathrm{S}-\mathrm{S}-\mathrm{S}-\mathrm{Ag}-\mathrm{S}-\mathrm{S}-\mathrm{S}-\mathrm{S}$, etc., were assumed to be zigzag chains. By taking into account the (probable) tetrahedral bond angles and lengths in the polysulfide chains and from $\mathrm{S}$ to $\mathrm{Ag}$ to $\mathrm{S}$, the chain lengths were estimated. The radius of silver was taken as equal to $1.35 \AA$ as given by GrEEN (1959) for $\mathrm{Ag}^{+1}$ in $\mathrm{Ag}_{2} \mathrm{O}$. The length of the polysulfide ions was estimated as in the first paper of this series. These lengths were then taken as $a_{0}$ 's in the Debye-Hückel theory, and approximate activity coefficients calculated on this basis. These activity coefficients were used in compiling Table 2. If the ions are bent at the silver atom instead of being "straight" 
the $a_{0}$ 's would be about half as large. The lengths chosen are $22 \AA$ for $\mathrm{Ag}\left(\mathrm{S}_{4}\right)_{2}{ }^{-3}, 24 \AA$ for $\mathrm{AgS}_{4} \mathrm{~s}_{5}{ }^{-3}$, and $15 \AA$ for $\mathrm{Ag}(\mathrm{HS}) \mathrm{S}_{4}{ }^{-2}$.

The equilibrium constants were then estimated as:

$$
\begin{array}{rlrl}
\mathrm{K}_{44} & =2.14 \times 10^{-8} ; & & \operatorname{Ag}_{2} \mathrm{~S}+4 \mathrm{~S}_{4}^{-2}=2 \mathrm{Ag}\left(\mathrm{S}_{4}\right)_{2}^{-3}+\mathrm{S}^{-2} \\
\mathrm{~K}_{45} & =1.74 \times 10^{-9} ; & & \operatorname{Ag}_{2} \mathrm{~S}+2 \mathrm{~S}_{4}^{-2}+2 \mathrm{~S}_{5}^{-2}=2 \mathrm{AgS}_{4} \mathrm{~S}_{5}^{-3}+\mathrm{S}^{-2} \\
\mathrm{~K}_{\mathrm{IS}_{4}}=2.95 \times 10^{4} ; & & \operatorname{Ag}_{2} \mathrm{~S}+\mathrm{H}^{1}+\mathrm{HS}^{-1}+2 \mathrm{~S}_{4}^{-2}=2 \mathrm{Ag}(\mathrm{HS}) \mathrm{S}_{4}^{-2}
\end{array}
$$

Copper polysulfide complexes

The great similarity of the solubility curves for acanthite and covellite suggests a similarity in the type of complex. Accordingly, the complex $\mathrm{Cu}\left(\mathrm{S}_{4}\right)_{2}{ }^{-3}$ was tested against the data given by HöltJe and BECkERT (1935) for the solubility of CuS in sodium polysulfide solutions. Once again the agreement is good except for high $\bar{y}$, and this can be largely corrected by assuming the

\begin{tabular}{|c|c|c|c|c|c|c|}
\hline \multirow[b]{2}{*}[\mathrm{Na}^{-1}]{} & \multirow[b]{2}{*}{$\bar{y}$} & \multicolumn{2}{|c|}{ Negative log of } & \multicolumn{2}{|c|}{$\mathrm{mg} / \mathrm{l}$} & \multirow{2}{*}{$\begin{array}{c}\text { Total } \\
\text { dissolved } \mathrm{C} \\
\mathrm{mg} / \mathrm{l}\end{array}$} \\
\hline & & $\left(\mathrm{Cu}\left(\mathrm{S}_{4}\right)_{2}^{-3}\right)$ & $\left(\mathrm{CuS}_{4} \mathrm{~s}_{5}^{-3}\right)$ & $\mathrm{Cu}\left(\mathrm{S}_{4}\right)_{2}^{-3}$ & $\operatorname{Cus}_{4} \mathrm{~s}_{5}^{-3}$ & \\
\hline $2 \cdot 56$ & $3 \cdot 0$ & $3 \cdot 30$ & $4 \cdot 27$ & $132 \cdot 5$ & $12 \cdot 6$ & $145 \cdot 1$ \\
\hline $1 \cdot 28$ & $4 \cdot 9$ & $3 \cdot 43$ & $2 \cdot 94$ & $94 \cdot 7$ & $262 \cdot 0$ & 350.7 \\
\hline $1 \cdot 28$ & $4 \cdot 5$ & $3 \cdot 28$ & $3 \cdot 23$ & $133 \cdot 7$ & $133 \cdot 5$ & $267 \cdot 2$ \\
\hline $1 \cdot 28$ & $4 \cdot 0$ & $3 \cdot 34$ & $3 \cdot 81$ & $116 \cdot 0$ & $35 \cdot 3$ & $151 \cdot 3$ \\
\hline $1 \cdot 28$ & $3 \cdot 0$ & $3 \cdot 75$ & $4 \cdot 63$ & $45 \cdot 0$ & $5 \cdot 3$ & $50 \cdot 3$ \\
\hline $1 \cdot 28$ & $2 \cdot 5$ & $4 \cdot 02$ & $5 \cdot 00$ & $24 \cdot 0$ & $2 \cdot 3$ & $26 \cdot 3$ \\
\hline $1 \cdot 28$ & $2 \cdot 0$ & $4 \cdot 40$ & $5 \cdot 46$ & $10 \cdot 0$ & $0 \cdot 8$ & $10 \cdot 8$ \\
\hline $1 \cdot 28$ & $1 \cdot 5$ & $4 \cdot 99$ & $6 \cdot 15$ & $2 \cdot 6$ & $0 \cdot 2$ & $2 \cdot 8$ \\
\hline $1 \cdot 0$ & $3 \cdot 0$ & $3 \cdot 92$ & $4 \cdot 76$ & $30 \cdot 2$ & $3 \cdot 9$ & $34 \cdot 1$ \\
\hline $1 \cdot 0$ & $1 \cdot 3$ & $\tilde{n} \cdot 01$ & $4 \cdot 29$ & $2 \cdot 4$ & $11 \cdot 3$ & $13 \cdot 7$ \\
\hline $0 \cdot 6$ & $3 \cdot 0$ & $4 \cdot 26$ & $5 \cdot 01$ & $13 \cdot 3$ & $2 \cdot 1$ & $15 \cdot 4$ \\
\hline $0 \cdot 2$ & $3 \cdot 0$ & $4 \cdot 93$ & $5 \cdot 49$ & $3 \cdot 9$ & $0 \cdot 6$ & $4 \cdot 5$ \\
\hline
\end{tabular}
presence of $\mathrm{CuS}_{4} \mathrm{~S}_{5}^{-3}$ as is shown in Fig. 1 and by the data listed in Table 3. No data are

Table 3. Calculated solubilities of covellite

available for lower $\mathrm{pH}$, and consequently the stability constant for $\mathrm{Cu}\left(\mathrm{HS}_{3}\right) \mathrm{S}_{4}^{-2}$ cannot be estimated.

If the activity coefficients for these complex ions are estimated as in the last section, the equilibrium constants are:

$$
\begin{array}{ll}
2 \mathrm{CuS}+\mathrm{S}_{3}^{-2}+3 \mathrm{~S}_{4}^{-2}=2 \mathrm{Cu}\left(\mathrm{S}_{4}\right)_{2}^{-3}+\mathrm{S}^{-2} ; & \mathrm{K}_{44}=5.00 \times 10^{-2} \\
2 \mathrm{CuS}+3 \mathrm{~S}_{4}^{-2}+\mathrm{S}_{5}^{-2}=2 \mathrm{CuS}_{4} \mathrm{~S}_{5}{ }^{-3}+\mathrm{S}^{-2} ; & \mathrm{K}_{45}=3.63 \times 10^{-7}
\end{array}
$$

These were used to compile Table 3 .

Several complexes between polysulfides and cupric ion were tested, but none gave satisfactory agreement with the data. The only cuprous-polysulfide complexes that gave reasonable agreement are those listed above.

\section{Galculations at other concentrations}

The constants derived above can also be used to estimate the solubilities of acanthite and covellite at other concentrations by making estimates of the activity coefficients. Some of the results are shown in Tables 1,2 , and 3 and in Figs. 3 and 4 . The agreement for acanthite is good at $\left[\mathrm{Na}^{+1}\right]=0.6$ but less satisfactory at $\left[\mathrm{Na}^{+1}\right]=0.2$. For covellite the agreement is good at $\left[\mathrm{Na}^{+1}\right]=0.26$ but poor at $\left[\mathrm{Na}^{+1}\right]=2.56$; this is probably due to the use of the Debye-Hückel equation for estimating activity coefficients in a range of ionic strengths far higher than that in 
which it is usually valid. This equation, however, supplies the only means of estimating the activity coefficients.

\section{Geologto Signtficance}

General

The significance of these results for geologic processes is difficult to assess. First of all the temperature and pressure used for the experiments are greatly different from those existing during hydrothermal deposition. Second, these are not true equilibrium studies because of the fact that the polysulfides have not disproportionated to sulfate and hydrosulfide as should be the case for equilibrium. Equilibrium might be achieved at higher temperatures, however. Third, if true equilibrium conditions did prevail in these experiments, appreciable amounts of polysulfide ions would be present in only one small area of the $\mathrm{Eh}-\mathrm{pH}$ diagram for sulfur, namely close to $\mathrm{pH}=8.0$ and $\mathrm{Eh}=-0.285 \mathrm{~V}$ for solutions $1 \mathrm{M}$ in $\mathrm{Na}^{+1}$. The lack of data on the heat capacities and compressibilities of sulfur-bearing anions does not permit a final evaluation of the change in size of this area with temperature and pressure. Fourth, a study of copper sulfides shows that chalcocite is converted to covellite by reaction with polysulfides if $\bar{y}$ is greater than 1.02 . Since primary chalcocite occurs in some hydrothermal deposits, this implies that the $\bar{y}$ was never very high. If so, no appreciable $\mathrm{Cu}$ or $\mathrm{Ag}$ could have been dissolved in polysulfide solutions. The $\bar{y}$ at which chalcocite converts to digenite, or digenite to covellite, at higher temperatures is not known; this $\bar{y}$ may be markedly higher than at room temperature. This is considered in more detail in a subsequent section of this paper where it is concluded that the experiments on the solubility of covellite and acanthite may have considerable importance in explaining the formation and localization of ore deposits.

\section{Effect of temperature and pressure on solubility}

Figure 6 shows that increasing temperature at constant total pressure increases the solubility of acanthite. HöLTJE and BECKERT (1935) found approximately the same percentage increase of solubility for covellite. To project the solubilities to higher temperatures and pressures it is assumed that the density of the solution is a more significant variable than either pressure or temperature independently. Certainly this is true for the (unhydrated) dissociation constants of water, $\mathrm{KCl}, \mathrm{HCl}$, and $\mathrm{KOH}$ (Frank, 1956); for the dielectric constant of water (Frank, 1956); and for the solubility of quartz in water (KENNEDY, 1950). Since the density of water is approximately constant up to $100^{\circ} \mathrm{C}$ at $1 \mathrm{~atm}$ pressure, the curves of Figs. 2 and 6 give approximately the change in solubility along a constant density or constant specific volume path (isochor). In keeping with this and with KENNEDY's (1950) results for quartz it is postulated that the solubility increases with temperature along all isochors. The theoretical discussion of WASSERBURG (1958) on the solubility of solids, especially quartz in water, lends support to this postulate.

To estimate the differences of solubility between isochors at the same temperature it is noted that solutions with a very large specific volume are more like gases than those with small specific volumes. Since solids are generally less soluble in gases than in liquids, it is presumed that an increase of specific volume at constant temperature causes a decrease of solubility. This again is analogous to the situation in the quartz-water system (KENNEDY, 1950). 
At sufficiently high temperatures large complexes may be expected to become unstable because of excessive thermal motion. This breakdown would undoubtedly change the relations deduced above to a large extent. It is at present impossible to predict the temperature at which breakdown begins. The hydrogen polysulfides are unstable at room temperature, suggesting that the long chains are unstable. However, recent work by BARNES (1960) has shown an increase of stability of $\mathrm{H}_{2} \mathrm{~S}_{x}$ molecules at higher temperatures. Polysulfide chains in the alkali polysulfides and in aqueous solutions have much greater stability than the hydrogen polysulfides at room temperature. Mere length of a chain does not mean that a compound will break down at high temperatures, as is evidenced by the fact that the lower members of the normal saturated hydrocarbons persist to temperatures of $1000^{\circ} \mathrm{C}$ or more. Lacking other information it is assumed here that polysulfides are stable in aqueous solution at hydrothermal and low magmatic temperatures.

\section{Attainment of equilibrium}

VAlensi (1951) and Garrels and Naeser (1958) have recently presented the equilibrium diagram for sulfur species at $25^{\circ} \mathrm{C}$ and $1 \mathrm{~atm}$. Examination of this diagram quickly reveals that the polysulfide ions do not appear as principal species. They do, however, assume appreciable concentrations close to the alkaline termination of the native sulfur field as shown in Fig. 8 . Figure 8 shows the lines along which

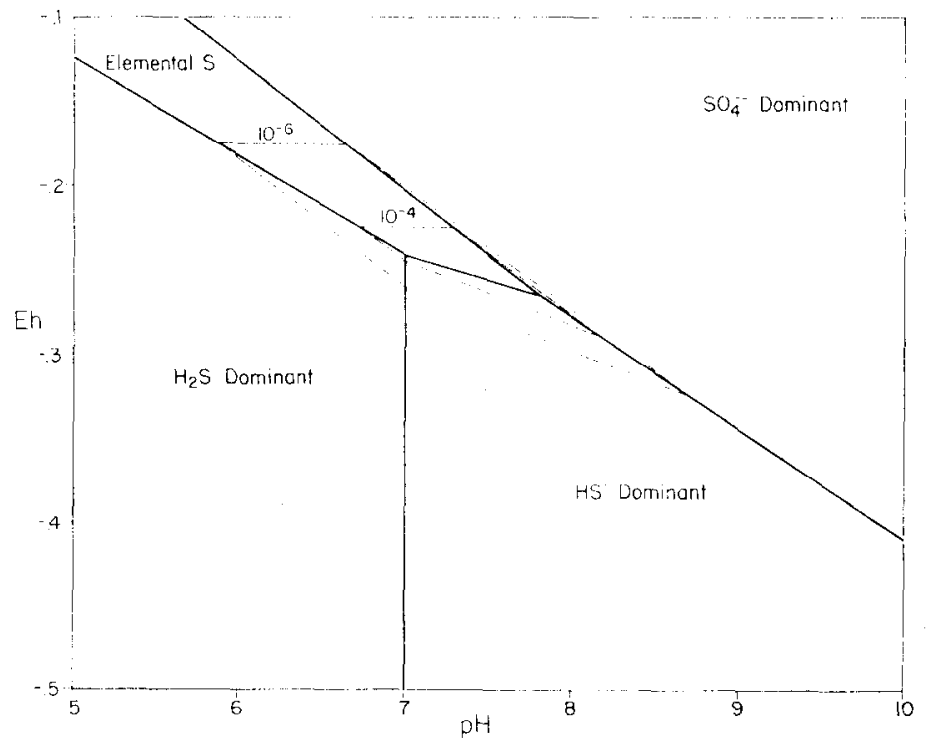

Fig. 8. Contours of $s_{5}^{-2}$ activity superimposed on the Eh-pH stability diagram of sulfur. 'Total dissolved $S=0 \cdot 1$ mole/1. Numbers refer to activity of $\mathrm{S}_{5}^{-2}$.

pentasulfide ion has activities of $10^{-6}$ and $10^{-4}$ in the equilibrium Eh-pH diagram of sulfur for solutions $0.1 \mathrm{M}$ in $\mathrm{Na}^{+1}$ (assuming activity coefficients of 1.0 and that no other ions are present). Calculated activities for other sulfur species are given by GaRRELS and NaESER (1958). It is noteworthy that the Eh and $\mathrm{pH}$ ranges in which appreciable amounts of polysulfides can exist in true equilibrium correspond to 
those suggested by BARTON $(1957,1959)$ for the ore-carrying solution. The concentration of polysulfides in the region of ore transport suggested by BARNES and KULLERUD (1961) is insignificant at room temperature.

Figure 9 shows the calculated molarities of two silver containing complexes with changing Eh and $\mathrm{pH}$ in solutions containing $0 \cdot 1$ mole of $\mathrm{S} / 1$. At any given point the total solubility of acanthite is the sum of the concentrations of all the complexes in solution. The concentration of the $\mathrm{Ag}(\mathrm{HS}) \mathrm{S}_{4}{ }^{-2}$ complex is at a maximum of ca $10^{-5 \cdot 0}$ near the alkaline tip of the elemental sulfur field; its molarity decreases

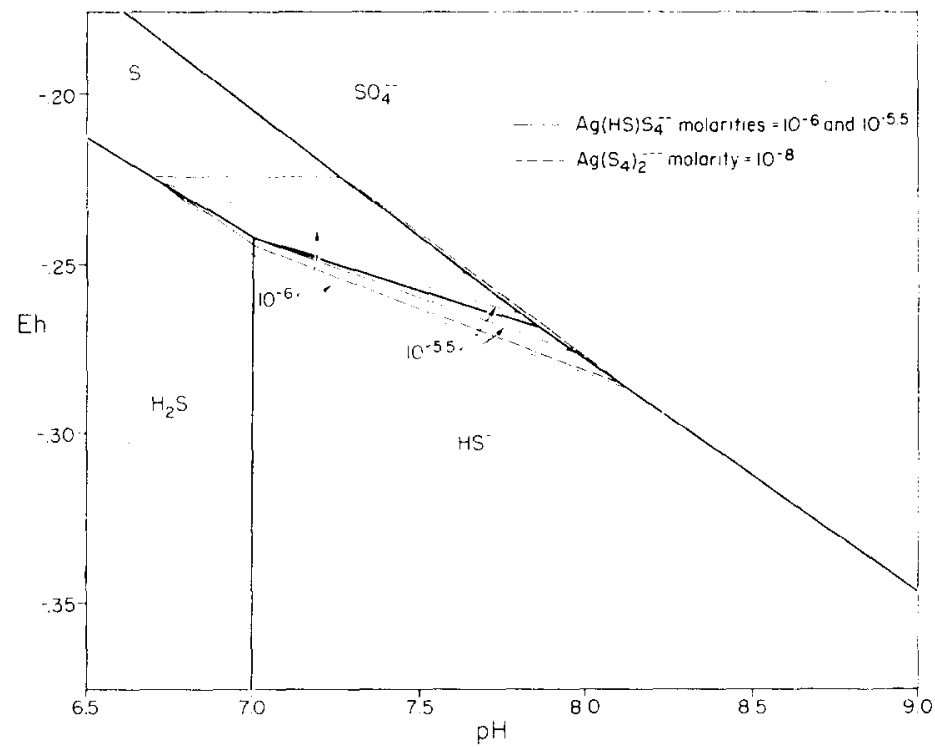

Fig. 9. Contours of the molarities of various silver containing complexes superimposed on the stability diagram of sulfur. Total dissolved $S=0 \cdot 1$ mole/l.

away from this point as shown by the contours on Fig. 9. The $\operatorname{Ag}\left(\mathrm{S}_{4}\right)_{2}{ }^{-3}$ and $\mathrm{AgS}_{4} \mathrm{~S}_{5}{ }^{-3}$ comlpexes likewise have maxima near the alkaline tip of the elemental sulfur field. The maximum concentrations of both are about $10^{-6 \cdot 5}$. The decrease of molarity of $\mathrm{Ag}\left(\mathrm{S}_{4}\right)_{2}{ }^{-3}$ away from this point is indicated by the $10^{-8}$ contour on Fig. 9. The decrease of molarity of $\mathrm{AgS}_{4} \mathrm{~S}_{5}{ }^{-3}$ is similar.

The contours representing the sum of these conecntrations closely approximate those of $\mathrm{Ag}(\mathrm{HS}) \mathrm{S}_{4}^{-2}$ alone. Any increase in the stability of polysulfides relative to $\mathrm{H}_{2} \mathrm{~S}, \mathrm{HS}^{-1}$, and $\mathrm{SO}_{4}^{-2}$ or of silver polysulfide complexes relative to silver sulfide will give a higher solubility "peak" around the alkaline tip of the native sulfur field.

The calculated solubilities imply that the most favorable conditions for transport of Ag lie close to the "peak". Garrels (1960) considers that an activity less than $10^{-8} \mathrm{~mole} / \mathrm{l}$. is insignificant geologically. KRAUSKOPF (1951) considered a concentration of $10^{-7} \mathrm{gm} / \mathrm{l}$. significant but later, as cited by Czamanske (1959), amended this to $10^{-5} \mathrm{gm} / \mathrm{l}$. as a more realistic minimum. For $\mathrm{Ag} 10^{-5} \mathrm{gm} / \mathrm{l}$. would be $10^{-7}$ mole/1. Thus, all of the contours shown in Fig. 9 may have geologic significance.

OGRYzLo (1935) attempted to measure the solubility of gold in polysulfide solutions at $300^{\circ} \mathrm{C}$. The solutions which he recovered were colorless, indicating that 
the polysulfide disproportionated to other species. This is indeed what should have happened since his solutions were strongly alkaline. From his results it may be inferred that the sulfur species are more likely to be in thermodynamic equilibrium at high temperature than at $25^{\circ} \mathrm{C}$.

Table 4. Free energies of complexes

\begin{tabular}{lc}
\hline Complex & $\Delta F^{\circ}$, kcal $/$ mole \\
\hline$A g\left(\mathrm{~S}_{4}\right)_{2}{ }^{-3}$ & $22 \cdot 45 \pm 0 \cdot 5$ \\
$A g \mathrm{~S}_{4} \mathrm{~S}_{5}^{-3}$ & $22 \cdot 88 \pm 0 \cdot 5$ \\
$\mathrm{Ag}\left(\mathrm{HS}_{\mathrm{S}} \mathrm{S}_{4}^{-2}\right.$ & $10 \cdot 09 \pm 0 \cdot 5$ \\
$\mathrm{Cu}\left(\mathrm{S}_{4}\right)_{2}^{-3}$ & $13 \cdot 41 \pm 3 \cdot 0$ \\
$\mathrm{Cu} \mathrm{S}_{4} \mathrm{~S}_{5}^{-3}$ & $14 \cdot 40 \pm 0 \cdot 5$ \\
\hline
\end{tabular}

\section{Eh-pH diagram for sulfur at high pressure and temperature}

The data which are available for calculating the Eh-pH diagram for $\mathrm{S}$ species at higher temperatures and pressures are not entirely satisfactory. At the present time, because of the lack of more precise data, it is necessary to assume that volume changes are negligible so that $\left[\partial\left(\Delta F^{\circ}\right) / \partial P\right]_{T}=\Delta V=0$ and that $\Delta H^{\circ}$ in the van't Hoff equation, $\left(\partial \log _{\mathrm{e}} K / \partial T\right)_{P^{\prime}}=\Delta H^{\circ} / R T^{2}$ is independent of temperature. In these equations $\Delta H^{\circ}$ is the standard enthalpy of reaction, $\Delta F^{\circ}$ the standard free energy, $\Delta V$ the change of volume, $R$ the gas constant, $T$ the absolute temperature, $(\partial / \partial P)_{T}$ the partial derivative with respect to pressure at constant temperature, and $(\partial / \partial T)_{P}$ the partial derivitive with respect to temperature at constant pressure. By making these assumptions, an approximate Eh-pH diagram can be calculated for higher temperatures. The data for polysulfides are somewhat less certain than for the other ions. The only enthalpy data which seem reasonably good are those given by Maronsy (1959). As mentioned in the first paper of this series (Cloke, 1963) MARONry assumes, probably erroneously, that $\mathrm{S}_{6}{ }^{-2}$ does not exist, and obtains somewhat different free energy values than in the present work.

The Eh-pH diagram calculated for $200^{\circ} \mathrm{C}$ using Maronny's data shows that the polysulfides are not more stable relative to $\mathrm{SO}_{4}{ }^{-2}$ and $\mathrm{HS}^{-1}$ than at room temperature. Nevertheless, there is enough uncertainty in the data to allow an interpretation in which a small but significant polysulfide field is present.

\section{Conversion of chalcocite to digenite and covellite}

A separate set of experiments has shown that $S$ can be added to precipitated chalcocite to form digenite at a $\bar{y}$ of about 1.01 , and the digenite can in turn be converted to covellite at a $\bar{y}$ of about 1.02. At higher $\bar{y}$ 's only covellite is stable. At these very low $\bar{y}$ 's practically no $\mathrm{Cu}$ or $\mathrm{Ag}$ would be in solution. The presence of both chalcocite and covellite in hypogene deposits would seem to require that the $\bar{y}$ of any polysulfides present should be low. Thus if polysulfide solutions are to act as ore carriers it would appear that $\bar{y}$ should be high in order to dissolve enough $\mathrm{Cu}$, but low in order to deposit chalcocite.

This contradiction may not be insurmountable, however. As covellite is heated it tends to lose $S$ to become digenite or chalcocite. Roseboom and KuLLerud (1958) have found that covellite loses $\mathrm{S}$ to become digenite at $507^{\circ} \mathrm{C}$ in the presence of sulfur vapor and a S-rich liquid. Thus above this temperature even a polysulfide 
solution saturated in sulfur would not have a $\bar{y}$ high enough to convert chalcocite to covellite. Presumably at lower temperatures the conversion point lies somewhere between saturation (high $\bar{y}$ ) and practically no $\mathrm{S}$ (very low $\bar{y}$ ); in this intermediate range of temperatures it seems likely that the solubilities of $\mathrm{Cu}$ and $\mathrm{Ag}$ would be high.

\section{Deposition from polysulfide solutions}

On the basis of the preceding results and arguments the hypothesis that chalcophile elements can be transported by aqueous solutions containing polysulfides seems reasonable. If so, it is interesting to consider various possible mechanisms for deposition from these solutions.

From the preceding discussion concerning the formation of silver-polysulfide complexes there emerge two important factors affecting solubility at constant temperature. The first is that reactions with acid, elemental sulfur, or polysulfide ions reduce the activity of sulfide ion. This reduction of sulfide ion causes more of the metal sulfide to dissolve. This factor applies to any chalcophile cation including those that may not form complexes with polysulfide ions. Reduction of sulfide ion activity makes it easier for complexes to form, and thus indirectly permits greater solubility. The second factor is that the higher are the contents of tetrasulfide and pentasulfide ions the greater are the amounts of silver-polysulfide complexes and the greater the solubility. If other anions (such as chloride) which form complexes with metal ions are present these would simply increase the solubility. Thus the second factor in essence requires merely that there be a sufficient amount of some complexing anion. In this paper only the case in which the cation (e.g. $\mathrm{Ag}^{+1}$, or $\mathrm{Cu}^{+1}$ ) forms complexes with polysulfide will be discussed; consideration of elements such as mercury, which seem to form complexes with sulfide but not with polysulfides (Dickson and TUnell, 1955), or those which form neither sulfide nor polysulfide complexes (iron?) will be omitted.

The two principal factors just discussed may be used to clarify several ways in which silver sulfide might be deposited from a polysulfide solution:

(a) Deposition by change of $\mathrm{pH}$. Examination of Fig. 7 shows that if the $\mathrm{pH}$ is increased at a constant $\bar{y}$ the solubility of acanthite decreases. This increase could be brought about by adding alkali, as demonstrated by the precipitation of acanthite during the experimental work. In nature an increase of $\mathrm{pH}$ might be caused by reaction with the wall rocks, as exemplified by the alteration of orthoclase to sericite or kaolinite (ef. HemLey, 1959) or reaction with limestone. The $\mathrm{OH}^{-1}$ reacts with $\mathrm{HS}^{-1}$ to produce $\mathrm{S}^{-2}$ and $\mathrm{H}_{2} \mathrm{O}$. This increase of $\mathrm{S}^{-2}$ represses the formation of the polysulfide complexes. The $\mathrm{S}^{-2}$ also reacts with the higher polysulfide ions (hexasulfide and pentasulfide) and decreases their concentrations to produce more $\mathrm{S}_{4}{ }^{-2}$; this reduces the solubility further. Thus increase of $\mathrm{pH}$ at constant $\bar{y}$ causes marked precipitation of acanthite. If the $\mathrm{pH}$ is raised by admixture of alkaline ground water with the polysulfide solution, there may be appreciable effects from dilution.

The discussion of the last paragraph presumes that the polysulfides may exist metastably after the increase of $\mathrm{pH}$. Experimentally this is found to be true at room temperature, but this situation may not exist at the elevated temperatures of hydrothermal solutions. If metastable conditions did not persist, an increase of $\mathrm{pH}$ would lead to a disproportionation of polysulfides to $\mathrm{S}^{-2}$ and $\mathrm{SO}_{4}^{-2}$. In this case the 
concentrations of $\mathrm{S}_{4}^{-2}$ and $\mathrm{S}_{5}^{-2}$ are greatly diminished, that of $\mathrm{S}^{-2}$ augmented, and the solubility greatly lessened. If no $\mathrm{SO}_{4}{ }^{-2}$ were present originally, $\mathrm{Ba}^{+2}$ would be very soluble in the polysulfide solution and production of the $\mathrm{SO}_{4}^{-2}$ would deposit barite. Alunite and other hypogene sulfates could originate similarly.

Decrease of $\mathrm{pH}$ can also cause deposition of acanthite. If the solution is initially saturated in sulfur, addition of acid will bring about the disproportionation of polysulfides to form sulfur and $\mathrm{HS}^{-1}$ thereby reducing the amounts of $\mathrm{S}_{4}{ }^{-2}$ and $\mathrm{S}_{5}{ }^{-2}$. This will tend to precipitate acanthite. At the same time, however, $\mathrm{S}^{-2}$ reacts to form $\mathrm{HS}^{-1}$ and this tends to dissolve acanthite. For $\mathrm{pH}$ values greater than nine these two opposing tendencies nearly cancel each other as is evidenced in Fig. 7 by the nearly constant solubility along the line labeled "saturated in sulfur" for $\mathrm{pH}$ 's between nine and eleven. If the $\mathrm{pH}$ is below nine the former tendency is dominant, and addition of acid causes deposition. This is shown by the strong dependence of solubility on $\mathrm{pH}$ ulong the "saturated in sulfur" line at pH's less than nine. Again there may be some secondary effects from dilution.

Addition of acid to a solution unsaturated in sulfur would increase the solubility along a constant $\bar{y}$ curve, then decrease it after the sulfur saturation curve was reached. For example, along the $\bar{y}=2 \cdot 0$ curve shown in Fig. 7 the solubility of acanthite would increase from 2 or $3 \mathrm{mg}$ of $\mathrm{Ag} / \mathrm{l}$. at $\mathrm{pH} 1.3$ to about $58 \mathrm{mg}$ of $\mathrm{Ag} /$ l. at $\mathrm{pH} 8 \cdot 25$. At this $\mathrm{pH}$ further addition of acid causes a reduction of $\bar{y}$ and a drop of solubility along the "saturated in sulfur" line. The discussion in this and the preceding paragraph also assumes the persistence of polysulfides in a metastable state. Drastic modification would be required if only stable states could persist.

A suitable source of acid is hard to visualize. Acid gases are known in volcanic emanations. Since the hydrothermal fluid presumably is also derived from igneous activity, it would seem that, if acids ever are added, the hydrothermal fluid should at some time become separated from acid gases and later recombined with them. Perhaps this could come about by solution of the acid gases in groundwater and later mixing of the ore fluid and the groundwater. Presumably this would occur only near surface and in siliceous or highly altered rocks which are not attacked by acids. The rarity of native sulfur in hydrothermal sulfide deposits may reflect a rarity of addition of acid to ore solutions. Possibly other circumstances may lead to a combination of acids with the ore fluid (e.g. feldspathization of clay minerals).

(b) Deposition by oxidation or reduction. Deposition of acanthite is readily produced by oxidizing both the polysulfide and sulfide ions to other species. This effect is observed in the experimental work during the oxidation by hydrogen peroxide. In nature both the hematite-magnetite and the hematite-pyrite boundaries on an Eh-pH diagram fall slightly above the region where polysulfides reach their maximum stable concentrations. Thus, hematite and other ferric compounds may act as oxidizing agents and cause the deposition of acanthite.

The reaction of hematite with sulfide ions (Griffith and Morcom, 1945; Pearson and Robinson, 1928; Foster, 1959) apparently produces $\mathrm{Fe}_{2} \mathrm{~S}_{3}$ and hydroxide as initial products acoording to the reaction

$$
\mathrm{Fe}_{2} \mathrm{O}_{3}+3 \mathrm{~S}^{-2}+3 \mathrm{H}_{2} \mathrm{O}=\mathrm{Fe}_{2} \mathrm{~S}_{3}+6 \mathrm{OH}^{-1}
$$

Magnetite also reacts with $\mathrm{S}^{-2}$. $\mathrm{Fe}_{2} \mathrm{~S}_{3}$ tends to break down spontaneously to 
$\mathrm{FeS}_{2}+\mathrm{FeS}$. The loss of $\mathrm{S}^{-2}$ from the solution caused by the reaction of a polysulfide solution with hematite would cause the breakdown of the polysulfide and the deposition of any dissolved acanthite or covellite. The $\mathrm{S}$ released by this breakdown should react with more hematite and the pyrrhotite to form more pyrite and some oxygen containing anion of $\mathrm{S}$ such as $\mathrm{S}_{2} \mathrm{O}_{3}{ }^{-2}, \mathrm{SO}_{3}{ }^{-2}$, or $\mathrm{SO}_{4}^{-2}$. In any case it seems likely that $\mathrm{pH}$ would increase and thus make sulfur more soluble because of its disproportionation to polysulfide and thiosulfate (ARNTson, Dickson, and TunelL, 1960). The polysulfide should then react with the hematite; the net effect is the same in either case, namely destruction of polysulfide, deposition of covellite and acanthite, and increase of $\mathrm{pH}$ with its attendant results. It would seem, therefore, that red beds should be mineralized by this process. Most rocks, however, contain insufficient hematite or magnetite to be very effective in oxidizing a large volume of polvsulfide solution.

It is interesting that reduction will also cause the precipitation of acanthite. In this case the polysulfides are decreased in amount by reduction to $\mathrm{S}^{-2}$ and the $\mathrm{S}^{-2}$ concentration in solution is increased by the same process. Thus, the solubility of acanthite or covellite is strongly repressed. Reduction might be caused by hydrogen, methane, or carbon monoxide in volcanic gases or by organic matter contained in sediments (e.g. black shales).

(c) Deposition by reaction with iron minerals. The effect of ferric compounds in the wall rocks in oxidizing the polysulfides has already been mentioned. The pyritization of either ferrous or ferric minerals in the wall rocks is also of interest. This pyritization may be visualized in two or three steps. Even though these steps are probably not the actual ones followed, the net result will be the same. If a ferric mineral is involved, the first step is the reduction to a ferrous state. This will involve the oxidation of some of the polysulfide and deposition of dissolved sulfides. The remaining steps can be considered in terms of ferrous compounds.

The details of the next step will depend strongly on the type of mineral present, e.g. oxide or silicate. It is instructive to consider a silicate case; for illustration the iron component of biotite is chosen. If the proper conditions are present this should alter to FeS and muscovite according to the reaction,

$$
\begin{aligned}
& \underset{\text { Fo biotite }}{3 \mathrm{KFe}_{3}\left(\mathrm{AlSi}_{3} \mathrm{O}_{10}\right)(\mathrm{OH})_{2}+9 \mathrm{HS}^{-1}} \\
& \quad=\underset{\text { muscovite }}{\mathrm{KAl}_{2}\left(\mathrm{AlSi}_{3} \mathrm{O}_{10}\right)(\mathrm{OH})_{2}}+9 \mathrm{FeS}+2 \mathrm{~K}^{+1}+6 \mathrm{SiO}_{2}+110 \mathrm{H}^{-1}+\mathrm{H}_{2} \mathrm{O}
\end{aligned}
$$

The final step then consists of reaction of the FeS with polysulfide to form pyrite, e.g.

$$
\mathrm{FeS}+\mathrm{S}_{5}^{-2}=\mathrm{FeS}_{2}+\mathrm{S}_{4}^{-{ }^{-2}}
$$

Other reactions for the second step can be chosen to correspond with the stability fields of various alteration products, such as kaolinite or montmorillonite. All these reactions produce a large amount of $\mathrm{OH}^{-1}$. As mentioned above the resultant increase of $\mathrm{pH}$ tends to decrease solubility of acanthite and to cause disproportionation of polysulfide. The increase of $\bar{y}$ caused by step two is more than offset by the other effects.

The silica produced during the pyritization is probably largely dissolved and carried away along with the $K^{+1}$ to make room for the sulfur atoms of the pyrite. 
It may contribute to silicification of the rock, however. The biotite in some instances is completely replaced by pyrite. In this case an additional "step" is simultaneously involved, namely, the replacement of the muscovite by pyrite.

This argument suggests that pyritization of wall rocks is not merely an accompaniment of hydrothermal deposition, but is actually a cause for the formation and localization of sulfide ore bodies.

(d) Deposition by dilution. Figures 2 and 5 show the solubility of covellite and acanthite as the concentration is increased at a constant $\bar{y}$. Since the curves are concave upward, it follows that dilution by a factor of two, for example, will decrease the solubility to a little less than half its former value. Since there is now twice as much solution, the amount dissolved is only slightly decreased.

(e) Deposition by drop of temperature or pressure. In view of the discussion in a previous section and of the experimental results presented in Fig. 3 for the effect of temperature alone it seems reasonable that a drop of either temperature or pressure would result in a marked deposition of acanthite or covellite. It is implicit here that the size of the stability region of polysulfides is not affected by temperature or pressure. If this is not the case, then changing conditions may either decrease the solubility by causing disproportionation of the polysulfides, or increase it by expanding the stable region of polysulfides. Presumably at a high enough temperature the polysulfides are thermally unstable. If so, a drop in temperature from this unstable range to a stable range would be expected to give rise to an increased solubility of silver sulfide, followed by a decrease in solubility with a further drop in temperature (at constant density).

\section{Origin and Destruction of Polysulfide Solutions in Nature}

This section is of necessity rather highly speculative. It is intended merely to show that reasonable geologic processes could lead to transport of metal sulfides by polysulfide solutions, and that geologic observations do not conflict with the suggested processes.

Since the high temperature relations of $\mathrm{S}$ are not well known, it is very difficult to postulate how polysulfide solutions might originate in nature. Because of the lack of definite information regarding the thermal stability of polysulfides it is here assumed that the aqueous solutions emanating from a crystallizing magma contain polysulfides and dissolved metals. This "ore" solution then moves upward and by one or more of the mechanisms outlined previously deposits the metals. Finally, as room temperature is approached the stability region of polysulfides decreases, and the polysulfides disproportionate to $\mathrm{HS}^{-1}$ and $\mathrm{SO}_{4}{ }^{-2}$. Most of the mechanisms for deposition involve directly or indirectly the destruction of polysulfides. This may explain the lack, to my knowledge, of any observation of polysulfides in fluid inclusions although both $\mathrm{H}_{2} \mathrm{~S}$ and $\mathrm{SO}_{4}{ }^{-2}$ have been found (SMITH, 1953).

\section{SUMMaRY}

In conclusion it has been shown that acanthite is appreciably soluble in sodium polysulfide solutions at room temperature. HöLTJE and BECKERT (1935) have shown that similar relations are true for the solubility of covellite. Use of data presented previously (CLOK E, 1963) made possible the calculation of the solubilities of 
acanthite and covellite in aqueous solutions having a wide range of $\mathrm{pH}$ and $\mathrm{S}$ content.

The significance of these results for the transport and deposition of sulfide ores was considered in some detail. Although large uncertainties are introduced by the lack of data at higher temperatures, it is possible that polysulfides may exist in the hydrothermal solution. On the assumption that polysulfides are present in the solutions emanating from crystallizing magmas various means of depositing the chalcophile elements from them were considered. Although no proof can be presented that these must be the solutions from which sulfide ore bodies formed, the results are geologically reasonable, lead to a simple explanation of barite and alunite formation, and suggest that pyritization of iron minerals and wall rock alteration may be causes of ore deposition. Favorable host rocks include any silicate rock capable of hydrothermal alteration, limestone, any iron-bearing rock, and black shales. Except for red beds, which are rarely mineralized, these correspond well with observed host rocks.

Acknowledgements-The author wishes to express his sincere appreciation of the encouragement and many helpful suggostions given by Professor RoBmnt M. Gannens of Harvard University. I also wish to thank the Committee on Experimental Geology and Geophysics for supporting this work. Professor F. S. Tunneaure of the University of Michigan has kindly read the manuscript and offered many valuable suggestions and MARAARET F. CUTHRFRT has checked the caloulations.

\section{REFERENCES}

Arntson R. H., Dtokson F. W. and Tunent G. (1960) Systems $\mathrm{S}-\mathrm{Na}_{2} \mathrm{O}-\mathrm{H}_{2} \mathrm{O}$ and $\mathrm{S}-\mathrm{H}_{2} \mathrm{O}$ : Application to the mode of origin of natural alkaline polysulfide and thiosulfate solutions. Amer. J. Sci. 258, 574-582.

Barnes H. I. (1960) Personal communication.

Barxes H. L. and Kullerud G. (1961) Equilibria in Sulfur-Containing Aqueous Solutions, In the System $\mathrm{Fe}-\mathrm{S}-\mathrm{O}$, And Their Correlation During Ore Deposition. Econ. Geol. 56, 648-688.

Barton P. B. Jr. (1957) Some limitations on the possible composition of tho ore-forming fluid, Econ. Geol. 52, 333-353.

Barton P. B. Jr. (1959) The Chemical Enviromment of Ore Deposition and the Problem of Low-temperature Ore Transport. In Researches in Geochemistry, Fdited by P. H. Abelson, $279-300$.

BJerrum J., Schwarzenbach G. and SildÉn L. G. (1958) Stability Constants, Part II, Inorganic Ligands, The Chemical Society, Burlington House, London.

Ctoke P. L. (1958) Solubility of Metal Sulfides in Dilute Vein Forming Solutions. Econ Geol. $53,494-496$.

CLoke P. L. (1961) The Transportation and Deposition of Chalcophile Metals by Sulfide and Polysulfide Complexes in Hydrothermal Solutions. Papers, Mich. Acad. Sci., Arts, and Letters XLVI, 5-18.

Cloke P. L. (1963) The geologic role of polysulfides, Part I, The distribution of anions in aqueous sodium polysulfide solutions, Geochim. et Cosmochim. Acta 27, 1265.

Czamansme G. K. (1959) Sulfide Solubility in Aqueous Solutions. Econ. Geol. 54, 57-63.

Dickson F. W. and Tunelx G. (1955) Geochemical and Petrographic Aspects of Mercury Ore Deposits, Final Report, Office of Naval Research, Contract Nonr 233, Task Order 12, Project NR 081-174.

Ewald P. P. and Hermann C. (1931) Strukturbericht, 1913-1928, Akademische Verlagsgesellschaft, M. B. H., Leipgig.

Fruḱr F. and Berthold H. J. (1953a) Beiträge zur Chemie des Schwefels, XIII, Die titrimetrische Bestimmung reiner Alkalipolysulfide, $Z$. anal. Chem. 138, 245-249.

Ferrér F. and Berthold H. J. (1953b) Beiträge zur Chemie des Schwefels, XIV, U̇ber das System Natrium-Schwefel, Z. anorg. Chem. 273, 144-160. 
Femér F., Laue W. and Winkraus G. (1957) Beiträge zur Chemie des Schwefels, XXXIV, Molvolumina und Molrefraktionen der Sulfane und ihre Abhängigkeit von der Kettenlänge, Z. anorg. Chem. 290, 52-57.

Foster P.K. (1959) The thermodynamic stability of iron and its compounds in hydrothermal media, N. Z.J.Sci. 2, 422-430.

Franch E. U. (1956) Hochverdichteter Wasserdampf I. Electrolytische Leitfähigkeit in $\mathrm{KCl}-\mathrm{H}_{2} \mathrm{O}$ Lösungen bis $750^{\circ} \mathrm{C}, Z$. phys. Chem. Neue Folge. 8, 92-106.

II, Ionendissoziation von $\mathrm{KCl}$ in $\mathrm{H}_{2} \mathrm{O}$ bis $750^{\circ} \mathrm{C}$, ibid. $107-126$,

$\mathrm{III}$, Tonendissoziation von $\mathrm{HCl}, \mathrm{KOH}$, und $\mathrm{H}_{2} \mathrm{O}$ in überkritischem Wasser, ibid, 192-206.

Garrels R. M. (1960) Mineral Equilibria. Harper, New York.

GarReLs R. M, and NAESER C. R. (1958) Equilibrium distribution of dissolved sulphur species in water at $25^{\circ} \mathrm{C}$ and 1 atm total pressure, Geochim et Cosmochim. Acta 15, 113-130.

Grees J. (1959) Geochemical table of the elements for 1959, Bull. Geol. Soc. Amer. 70, 1127-1184.

Griffith R. H. and Mondom A. R. (1945) The interconversion of iron oxides and sulfides, J. Chem. Soe. $786-790$.

HEMLEY J. J. (1959) Some mineralogical equilibria in the system $\mathrm{K}_{2} \mathrm{O}-\mathrm{Al}_{2} \mathrm{O}_{3}-\mathrm{SiO}_{2}-\mathrm{H}_{2} \mathrm{O}$. Amer. J. Sci. 25\%. 24.1-270.

HöLtJe R. and BEckдRT J. (1935) Die Löslichkeit von Kupfersulfid in Alkalipolysulfidlösungen, Z. anorg. Chem. 222, 240-244.

KENNEDY G. C. (1950) A portion of the sytem silica-water, Econ. Geol. 45, 629-653.

Krauskopf K. B. (1951) Physical Chemistry of Quicksilver Transportation in Vein Fluids. Econ. Geol. 46, 498-523.

Latimer W. M. (1952) The Oxidution Stutes of the Elements und their Potendiuls in Aqueous Solutions, 2nd ed., Prentice.Hall, New York.

Maronny G. (1959) Constantes de dissociation de l'hydrogène sulfuré Electrochim. Acta 1, $58-69$.

Natarajan R. (1958) Eh-pH diagram for the system Cu-Fe-S- $\mathrm{H}_{2} \mathrm{O}$, Personal Communication.

OGrYzlo S. P. (1935) Hydrothermal experiments with gold, Econ. Geol. 30, 400-424.

OL'Shanski YA. I., Ivanenko V. V. and Krromov A. V. (1959) The solubility of silver sulfide in aqueous solutions saturated with hydrogen sulfide, Alkad. Nauk SSSR, Dokl. Earth Sci. Secs., in Eng. Transl. 124, 9-12.

Pearson T. G and Robinson P. L. (1928) The reaction between monohydrated ferric oxide and hydrogen sulphide at $100^{\circ}, J$. Chem. Soc., 814-823.

Roseboom E. H., Jr. and KULt.enud G. (1958) The solidus in the system $\mathrm{Cu}-\mathrm{Fe}-\mathrm{S}$ between $400^{\circ}$ and $800^{\circ} \mathrm{C}$, Carnegie Inst. Wash. Year Book 57, 222-227.

Sмrтн F゙. (G. (1953) Historical Development of Inclusion Thermometry, Univ. of Toronto Press, Toronto, Ontario.

Treadweld W. D. and Hepenstrick H. (1949) L̇ber die Löslichkeit von Silbersulfid, Helv. Chim. Acta. 32, 1872-1879.

VALENSI C. (1951) Contribution au diagramme potentiol pH du Soufre, Proc., Second Meeting, Int. Comm. Electrochem. Thermodynam. Kinet. (CITCE), Libreria Editrice Politecnica Cesare Tamburini, Milan, 5168.

WasserbuRG G. J. (1958) The solubility of quartz in supereritical water as a function of pressure, J. Geol. 66, $559-578$. 